\title{
Can Managed Realignment Buffer Extreme Surges? The Relationship Between Marsh Width, Vegetation Cover and Surge Attenuation
}

\author{
Joshua Kiesel $^{1} \cdot$ Leigh R. MacPherson $^{2} \cdot$ Mark Schuerch $^{3} \cdot$ Athanasios T. Vafeidis $^{1}$
}

Received: 9 February 2021 / Revised: 13 July 2021 / Accepted: 14 July 2021 / Published online: 11 August 2021

(c) The Author(s) 2021

\begin{abstract}
Managed realignment (MR) involves the landward relocation of sea defences to foster the (re)creation of coastal wetlands and achieve nature-based coastal protection. The wider application of MR is impeded by knowledge gaps related to lacking data on its effectiveness under extreme surges and the role of changes in vegetation cover, for example due to sea-level rise. We employ a calibrated and validated hydrodynamic model to explore relationships between surge attenuation, MR width// area) and vegetation cover for the MR site of Freiston Shore, UK. We model a range of extreme water levels for four scenarios of variable MR width. We further assess the effects of reduced vegetation cover for the actual MR site and for the scenario of the site with the largest width. We show that surges are amplified for all but the largest two site scenarios, suggesting that increasing MR width results in higher attenuation rates. Substantial surge attenuation (up to $18 \mathrm{~cm} \mathrm{~km}^{-1}$ ) is only achieved for the largest site. The greatest contribution to the attenuation in the largest site scenario may come from water being reflected from the breached dike. While vegetation cover has no statistically significant effect on surge attenuations in the original MR site, higher coverage leads to higher attenuation rates in the largest site scenario. We conclude that at the open coast, only large MR sites ( $>1148 \mathrm{~m}$ width) can attenuate surges with return periods $>10$ years, while increased vegetation cover and larger MR widths enable the attenuation of even higher surges.
\end{abstract}

Keywords Managed realignment $\cdot$ De-embankment $\cdot$ Saltmarsh $\cdot$ Coastal restoration $\cdot$ Naturebased $\cdot$ Solutions $\cdot$ Surge attenuation

\section{Introduction}

The combination of accelerated sea-level rise (Dangendorf et al. 2019; Nerem et al. 2018) and projected increases in episodic flooding, particularly in regional hotspots such as north western Europe (Kirezci et al. 2020), is expected to lead to increased flood risk for low-lying coasts and higher adaptation costs (Hinkel et al. 2014). Problematically,

Communicated by Charles T. Roman

Joshua Kiesel

kiesel@geographie.uni-kiel.de

1 Department of Geography, Christian-Albrechts-Universität Zu Kiel, 24118 Kiel, Germany

2 Agricultural and Environmental Sciences, University of Rostock, 18059 Rostock, Germany

3 Lincoln Centre for Water and Planetary Health, School of Geography, University of Lincoln, Brayford Pool Campus, Lincoln LN6 7TS, England conventional protection measures such as dikes and seawalls are challenged by rising maintenance costs and ecologically disadvantageous side effects such as limited accommodation space due to coastal squeeze (Temmerman et al. 2013; Doody 2004; Schuerch et al. 2018).

The availability of accommodation space that allows for wetland inland migration will determine the survival of global coastal wetlands over the twenty-first century. Traditional hold-the-line approaches for adaptation to rising sea levels and associated flooding limit accommodation space and can lead to large-scale losses of coastal wetlands. Such losses may therefore be prevented by changing adaptation practices towards nature-based solutions (Spencer et al. 2016; Schuerch et al. 2018).

Nature-based coastal adaptation can provide a cost-effective alternative (Reguero et al. 2018) or complement conventional coastal defence schemes, as studies from the United Kingdom (UK) and the Scheldt estuary (Belgium) have shown (Turner et al. 2007; Broekx et al. 2011). Such practices additionally involve the creation or restoration of coastal wetlands such as 
saltmarshes (Temmerman et al. 2013), which can substantially reduce flood impacts (Barbier et al. 2013) and at the same time contribute to the conservation and restoration of biodiversity and more natural shorelines.

Two options are regularly implemented in Europe: managed realignment (MR) and regulated tidal exchange (RTE) (ABPmer 2021). RTE constitutes a more controlled way of re-establishing tidal exchange, by fully maintaining the first dikeline and applying water control structures such as sluices, culverts or tide gates (Oosterlee et al. 2020; Cox et al. 2006). Here, we focus on managed realignment, which aims at the re-establishment of coastal ecosystems to sustainably manage flood and erosion risks (Esteves 2013). MR constitutes the relocation of sea defences to more landward positions, followed by the breaching or removal of the old, seaward line of defence (French 2006). A detailed description of various MR types is given in Esteves (2014).

Using saltmarshes as a buffer zone for preventing lowlying coastal areas from flooding is based on evidence from a multitude of studies, which show the potential of vegetated surfaces to attenuate high water levels (HWL) (Paquier et al. 2017; Sheng et al. 2012; Smolders et al. 2015; Stark et al. 2015, 2016; Wamsley et al. 2010) and waves (Möller and Spencer 2002; Möller et al. 2014; Rupprecht et al. 2017). According to Smolders et al. (2015), HWL attenuation can be distinguished between within-wetland attenuation and along-estuary attenuation. The latter refers to the contribution of estuarine intertidal areas to reduce the height of storm surges that propagate upstream along an estuary, which is also referred to as water retention or flood water storage (Hofstede 2019; Oosterlee et al. 2020; Cox et al. 2006; Smolders et al. 2015). Within-wetland attenuation occurs over the wetland itself, due to shallow water depths and the resistance of vegetation (Stark et al. 2015, 2016; Temmerman et al. 2012; Loder et al. 2009; Wamsley et al. 2010, 2009). Several studies provide HWL attenuation rates in the range of $4 \mathrm{~cm} \mathrm{~km}^{-1}$ (Lovelace 1994; McGee et al. 2006; Wamsley et al. 2010) to $25 \mathrm{~cm} \mathrm{~km}^{-1}$ (McGee et al. 2006; Wamsley et al. 2010), all of which were measured over several kilometres. These rates clarify that marshes of $>1 \mathrm{~km}$ width are required for the provision of effective within-wetland attenuation.

Among the drivers of HWL attenuation are the characteristics of the surge (Resio and Westerink 2008), vegetation community properties (Temmerman et al. 2012; Barbier et al. 2013), marsh topography (Loder et al. 2009) and the presence of tidal creeks (Stark et al. 2016). Stark et al. (2016) found that saltmarshes dominated by channelized flow provide less HWL attenuation compared to those governed by sheet flow, which has also been shown for mangrove ecosystems (Montgomery et al. 2018). Mean flow velocity decreases logarithmically with increasing distance from the marsh margin in the direction of the current flow (Leonard and Croft 2006; Christiansen et al. 2000). Therefore, both withinwetland and along-estuary attenuation of HWLs should increase with larger wetland surface areas, even though along-estuary attenuation does not further increase above a certain threshold in site area (Smolders et al. 2015). The relationship between within-wetland attenuation and marsh width raises questions regarding the suitability of small wetland restoration schemes for providing HWL attenuation. Some studies suggested that the HWL attenuation potential of saltmarshes may be restricted by certain thresholds in inundation depth above the marsh platform. While Stark et al. (2015) found maximum attenuation rates for a water depth range between 0.5 and $1.0 \mathrm{~m}$, Wamsley et al. (2010) and Loder et al. (2009) show that very high storm surges may overwhelm the attenuating capacity of the ecosystem.

The example of Freiston Shore, Lincolnshire, UK, suggests that the effectiveness of saltmarshes restored within the scope of MR to reduce HWLs is highly variable and may not be equivalent to adjacent natural ecosystems (Kiesel et al. 2019). This may not be surprising, as previous studies have shown that HWL attenuation rates over saltmarshes generally vary in space and time and cannot be summarised to a single reduction factor (Resio and Westerink 2008; Reed et al. 2018). Differences in the HWL attenuation potential between natural and restored saltmarshes may originate from MR scheme design and differences in those ecosystem properties that drive their coastal protection function. These properties include, for example, vegetation characteristics (Mazik et al. 2010; Garbutt and Wolters 2008; Mossman et al. 2012) and topographic complexity (Lawrence et al. 2018).

Results from studies based on hydrodynamic modelling suggest that the coastal protection function of MR schemes can be improved by applying a scheme design (i.e. configuration of breaches and dikes) that aims at keeping internal water depths low, but attenuation rates $>10 \mathrm{~cm} \mathrm{~km}^{-1}$ are only achieved by establishing vast and wide shallow water areas (Kiesel et al. 2020). Problematically, MR sites are typically smaller than Freiston Shore (66 ha). According to the Online Managed Realignment Guide (OMREG) (ABPmer 2021), 71\% of the MR schemes registered in January 2021 across Belgium, Denmark, France, Germany, Netherlands, Spain and UK are smaller than Freiston Shore and 46\% smaller than 20 ha. Thus, the majority of MR schemes may not have the potential for effective within-wetland attenuation (Hofstede 2019). We note, however, that the majority of sites smaller than Freiston Shore and smaller than 20 ha (72\% and $73 \%$, respectively) are located in estuarine settings and may therefore still be effective in providing along-estuary attenuation. 
Two of the main knowledge gaps impeding the wider application of MR in coastal defence schemes are (1) missing studies on the effectivity of saltmarshes restored in the context of MR to attenuate the most extreme events and (2) shortage of information on long-term ecosystem dynamics under the influence of sea-level rise and more frequent flooding, which potentially lead to reduced ecosystem resilience and vegetation die-off. The latter can diminish the HWL attenuation potential of the ecosystem (Bouma et al. 2014; Wamsley et al. 2009; Temmerman et al. 2012; Barbier et al. 2013; Narayan et al. 2016). Saltmarsh vegetation may fail to establish in newly created MR schemes (Brooks et al. 2015) or die-off as a consequence of storm surges and associated wave climates (Rupprecht et al. 2017) and sea-level rise, directly followed by conversion to tidal flats (Kirwan et al. 2010; Marani et al. 2007) or ponds. Studies have indicated that the latter may result in a patchy distribution of vegetation (Schepers et al. 2020; Mariotti 2020; Vinent et al. 2021).

Here, we address these knowledge gaps by studying the effectiveness of HWL attenuation over the Freiston Shore MR site under a range of extreme water levels (10-, 50-, 100-, 200-, and 1000-year event) and three reduced vegetation scenarios, which assume patchy vegetation die-off. Further, we investigate thresholds to the HWL attenuation function of Freiston Shore in relation to marsh width by simulating the propagation of storm surges over four MR width scenarios. We additionally study how the largest MR width alters the relationship between extreme water level, vegetation scenarios and HWL attenuation. For this purpose, we use a hydrodynamic model of the Freiston Shore MR site, setup in Delft3D-Flow (Delft Hydraulics 2003), which has been calibrated and validated against field measurements of the highest spring tides for the year 2017 (Kiesel et al. 2020).

\section{Study Area and Methods}

\section{Study Area}

The MR site of Freiston Shore is situated in Lincolnshire, UK, at the west coast of The Wash embayment (Fig. 1b, c), a shallow (average water depth $<10 \mathrm{~m}$ ) and sheltered embayment on the east coast of England. The intertidal areas of the bay comprise various habitats such as saltmarshes, sand- and mudflats (Brew and Williams 2002). Tides in the embayment are semidiurnal and macrotidal, with neap- and springtide ranges of 3.5 and $6.5 \mathrm{~m}$, respectively (Ke et al. 1996).

The Wash has experienced numerous major storm surges in the past; the most severe occurred in 1953, resulting in the deaths of 307 people along the east coast of England (Baxter 2005). High water levels in the south-western Wash reached 5.48 m ODN (Ordnance Datum Newlyn, where
$0 \mathrm{~m}$ approximates mean sea level) at Haven Sluice, Boston (Fig. 1b). The total flood damage has been estimated at $£ 1.2$ billion (equivalent for the year 2014) (Wadey et al. 2015). In 2013, the storm 'Xaver' caused the highest still water levels on record at several tide gauges (Spencer et al. 2015). However, in contrast to 1953, no casualties were recorded, and total flood damage costs summed up to $£ 0.25$ billion (Spencer et al. 2015). Maximum water level elevations for Lincolnshire were measured at Donna Nook, reaching $5.83 \mathrm{~m}$ ODN (Spencer et al. 2015).

The Wash has a long history of land reclamation, and the latest dike (later also referred to as breached, seaward dike) was completed at Freiston Shore in 1982, to protect adjacent low-lying fenland as well as urban and agricultural areas (Friess et al. 2012). This dike was built further into The Wash than dikes to the north and south, exposing the foot of the dike to wave attack, and signs of erosion required repair and maintenance by the former owner, Her Majesty's Prisons (Brown et al. 2007). The 1996 Shoreline Management Plan recommended realignment of the coastal stretch at Freiston Shore (Spencer et al. 2012), and in 2002, 66 ha of new intertidal and shallow water habitats were restored by breaching the seaward dike at three locations (Fig. 1a) (Brown et al. 2007). Among the aims was the creation of a sustainable flood defence scheme through the establishment of saltmarsh (Brown et al. 2007). The final monitoring report confirmed that saltmarsh restoration was successful, as in 2007, mean total halophytic vegetation cover within the MR site was estimated at $89 \%$ (Brown 2008).

The analysis of a 2016 LiDAR (Light Detection and Ranging)-derived digital elevation model (DEM) (Environment Agency 2020) showed that the mean elevation inside the MR was $3.04 \pm 0.42 \mathrm{~m}$ ODN (Kiesel et al. 2019).

\section{Model Setup and Data Processing}

We simulated the propagation of surge water levels over the model domain (light grey mesh Fig. 1a) using the DELFT3D-FLOW (version 4.00.02) model (Delft Hydraulics 2003). This model calculates the flow of water over a multi-dimensional (2D (depth averaged) and 3D) finite, rectilinear or curvilinear, boundary-fitted difference grid. Areas of application include coastal, river and estuarine settings (Delft Hydraulics 2003; Lesser et al. 2004; Temmerman et al. 2012; Elahi et al. 2020).

We used the model to simulate two-dimensional flow over a Cartesian grid using the horizontal momentum equations, the continuity equation and 2D turbulence, which was modelled based on a constant horizontal eddy viscosity coefficient $\left(1 \mathrm{~m}^{2} \mathrm{~s}^{-1}\right)$. For a detailed description of the model and the governing equations, we refer the reader to the DELFT3D-FLOW user manual (Delft Hydraulics 2003). 

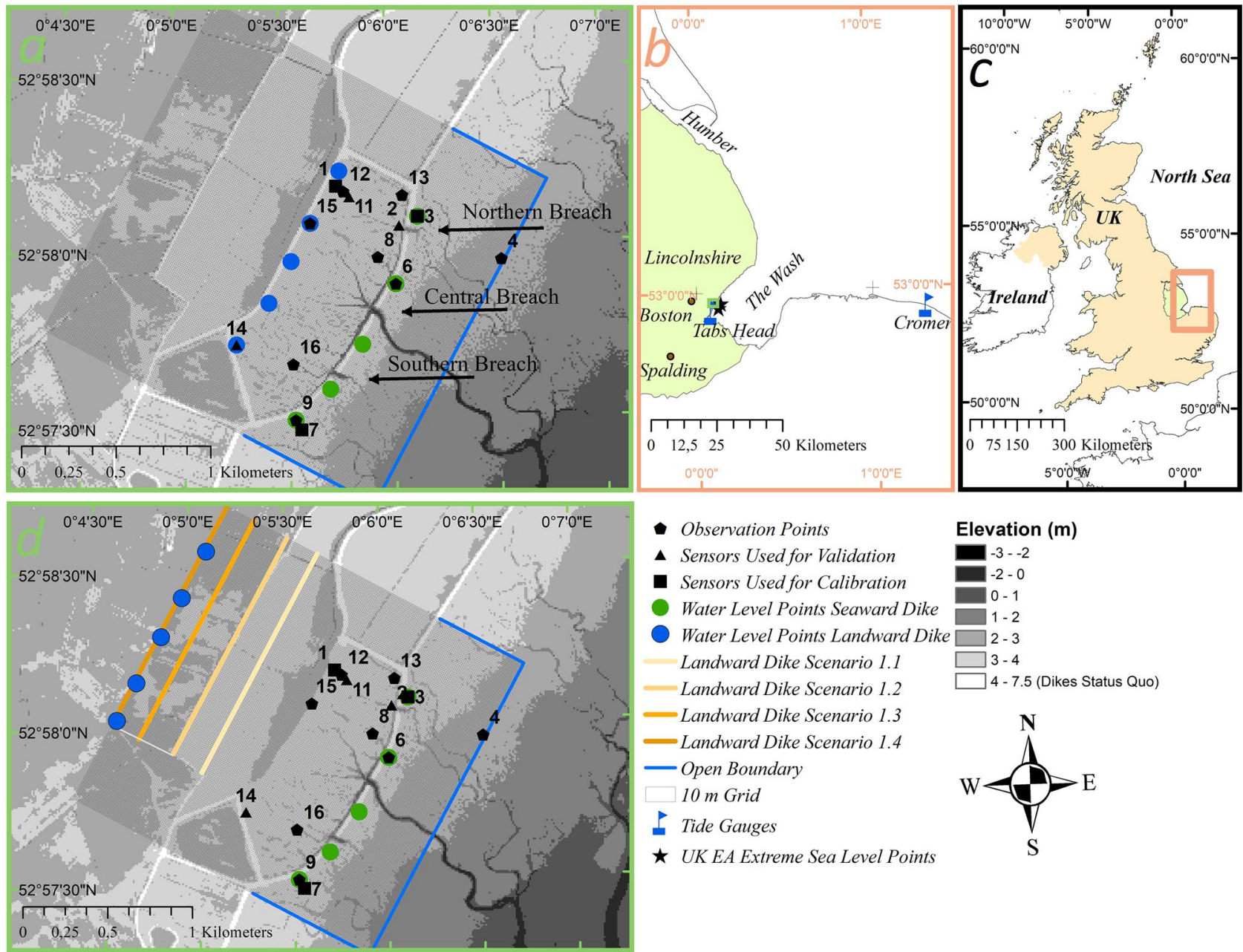

Fig. 1 a The model domain (indicated by $10 \mathrm{~m}$ grid) covers the Freiston Shore MR site, the adjacent natural marsh and neighbouring arable lands. Seaward open boundaries of the model domain (blue lines) are used to force the model with hydrographs of selected return water levels (see "Generation of Extreme Water Level Hydrographs"). In our model application, only the eastern side was forced, while the other two were allowed to exchange water with outside the model domain. The observation points are used to calculate HWL attenuation rates within the MR site. In addition, blue dots indicate observa-

The model domain covers an area of $1.97 \mathrm{~km}$ in width and $1.95 \mathrm{~km}$ in length. It extends from the pioneer zone of the natural saltmarsh in front of the MR over the MR itself into the adjacent agricultural lands (see coverage of $10 \mathrm{~m}$ grid in Fig. 1a). The model has been set up with three open boundaries (Fig. 1a), of which only the eastern side was forced with hydrographs representing the five return water level scenarios. All boundaries were allowed to exchange water outside the model domain. The temporal resolution of the five hydrographs was 10 minutes, and the model time step was 6 seconds.

Bathymetry, topography and land cover information to develop elevation and surface roughness maps of the model tion points in front of the landward dike and green dots are situated in front of the breached, seaward dike. b Location of the study area in The Wash embayment (green box), location of local tide gauges and points for which extreme return water levels were available. c Location of The Wash embayment in eastern England (orange box). d Model setup for the four tested MR width scenarios. Note that the landward dike of the status quo has been removed and new, artificial dikes were placed at the back of the model domain in varying distances

domain were derived from a $2 \times 2-\mathrm{m} 2016$ LiDAR-derived DEM (Environment Agency 2020) and a supervised image classification (Kiesel et al. 2019), which was based on $20 \times 20 \mathrm{~cm}$ vertical aerial photography from the same year (Environment Agency 2019c). In order to reduce computational costs, all data were resampled onto a $10 \times 10$-m grid, which was the base for the model calculations (Fig. 1a). The DEM was resampled by calculating the average of the four nearest cells. The supervised image classification was used to distinguish between dominant surface cover classes, namely saltmarsh, water and tidal flat (either sand or mudflat). These classes were used to derive the surface roughness within the model domain, which is represented in the model 
by assigning Manning's $n$ coefficients (saltmarsh 0.08 , tidal flat 0.03 and water 0.02 ). These values have been widely used in literature in hydrodynamic model applications and were shown to be suitable for representing the drag forces exerted by the respective surface type (Garzon and Ferreira 2016; Hossain et al. 2009; Lawrence et al. 2004; Liu et al. 2013; Wamsley et al. 2010, 2009; Smolders et al. 2015; Stark et al. 2016; Temmerman et al. 2012). Manning's $n$ coefficients for every cell $(20 \times 20 \mathrm{~cm})$ were resampled onto the $10 \times 10-\mathrm{m}$ grid by using the same approach as for the model's elevation.

In a previous study, the model was calibrated and validated against field measurements of the highest spring tides of the year 2017. Root mean square errors between modelled and measured water depths ranged between 0.05 and $0.06 \mathrm{~m}$ and mean absolute errors of peak water levels between 0.02 and $0.04 \mathrm{~m}$. Model calibration included a range of Manning's $n$ coefficients for saltmarsh surfaces (0.035-0.09) and revealed that the model was not very sensitive to these variations (Kiesel et al. 2020). We note that the effects of bottom friction are also dependent on water depth (Delft Hydraulics 2003; Loder et al. 2009; Wamsley et al. 2010; Temmerman et al. 2012), and the calibration of the model is representative of spring tide conditions.

\section{Generation of Extreme Water Level Hydrographs}

In order to support successful risk-based flood and coastal erosion management, the UK Environment Agency (EA) has published a consistent set of extreme sea levels around the coasts of England, Wales, Scotland and Northern Ireland. Extreme peak sea level heights for different annual exceedance probabilities are provided in the report for events with return periods that range between 1 and 10,000 years, at points every $2 \mathrm{~km}$ along the coastline (Environment Agency 2019b).

In order to analyse the attenuation of extreme sea levels within the Freiston Shore MR site, we selected the 10-, 50-, 100-, 200- and 1000-year events from the EA's report, referenced to ODN. Peak water levels for each return period were averaged from the two closest points to the Freiston Shore MR site (Fig. 1b). Both points are approximately $1.85 \mathrm{~km}$ seaward of the eastern open boundary. The resulting extreme water levels are $5.24 \mathrm{~m}$ for the $10-, 5.54 \mathrm{~m}$ for $50-, 5.67 \mathrm{~m}$ for $100-, 5.81 \mathrm{~m}$ for 200 - and $6.16 \mathrm{~m}$ for the 1000 -year event. It is likely that the extreme water levels would be attenuated to some extent while propagating from these points to the boundary of the model domain. It is therefore likely that we slightly overestimate the peak extreme water levels for each event.

To create the storm surge hydrographs which force the model, we followed the procedure described in the user guide to the EA's report (Environment Agency 2019a).
Unfortunately, no significant surges were recorded at the nearest tide gauge Tabs Head, which is why we took the hydrograph of the largest surge from the tide-gauge record at Cromer (ca. $81 \mathrm{~km}$ air-line distance from study site: Fig. 1b), which occurred in February 1993, with a maximum height of $2.5 \mathrm{~m}$ (Fig. 2a). We extracted the surge component of the event using the UTide Matlab functions (Codiga 2011) and combined it with tidal water levels recorded at Tabs Head (ca. $4 \mathrm{~km}$ air-line distance from study site: Fig. 1b). We then scaled each timestep of the surge component by a single factor in order to meet each of the respective target design water levels, as suggested by the EA's report. Each timestep of the new surge component $\left(S(t)_{\text {new }}\right)$ was scaled using the following equation:

$S(t)_{\text {new }}=S(t)_{\text {orig }} \cdot\left(1+\frac{d w l-p w l}{p w l}\right)$,

where $S(t)_{\text {orig }}$ is the original surge extracted from the tide gauge in Cromer, $d w l$ is the targeted design water level for each extreme event tested, and $p w l$ is the peak total water level at the tide gauge. Finally, the resulting new surge water level time series were recombined with the tidal data from Tabs Head. This procedure was repeated for each of the five design water levels, and the resulting hydrographs for each return water level were used as boundary conditions for the eastern open boundary and are shown in Fig. 2 b.

\section{MR Width Scenarios}

The effects of varying marsh widths (and consequently areas) were studied by removing the landward dike of the original Freiston Shore MR site (referred to as status quo) and implementing new seawalls (called thin dams in Delft3D-Flow) at the back of the site for four hypothetical (residential areas and roads are located within scenarios 1.3 and 1.4) MR width scenarios (Fig. 1d). Marsh width was measured from the central breach perpendicular to the coastline in a landward direction. Scenario 1.1 covers an area of 118 ha with a $900 \mathrm{~m}$ MR width, 1.2145 ha and $1100 \mathrm{~m}, 1.3$ 180 ha and $1320 \mathrm{~m}$ and 1.4205 ha and $1500 \mathrm{~m}$ width. We assumed full vegetation cover for all MR width scenarios.

\section{Vegetation Scenarios}

We explore the propagation of extreme HWLs for three scenarios of reduced vegetation cover over the Freiston Shore MR site and scenario 1.4. These two model setups were chosen as they represent the greatest difference between MR widths (and areas). The original vegetation, determined from the supervised image classification (see "Model Setup and Data Processing"), was found to cover $81 \%$ in the north of the MR and 73\% in the south (Kiesel et al. 2019). 

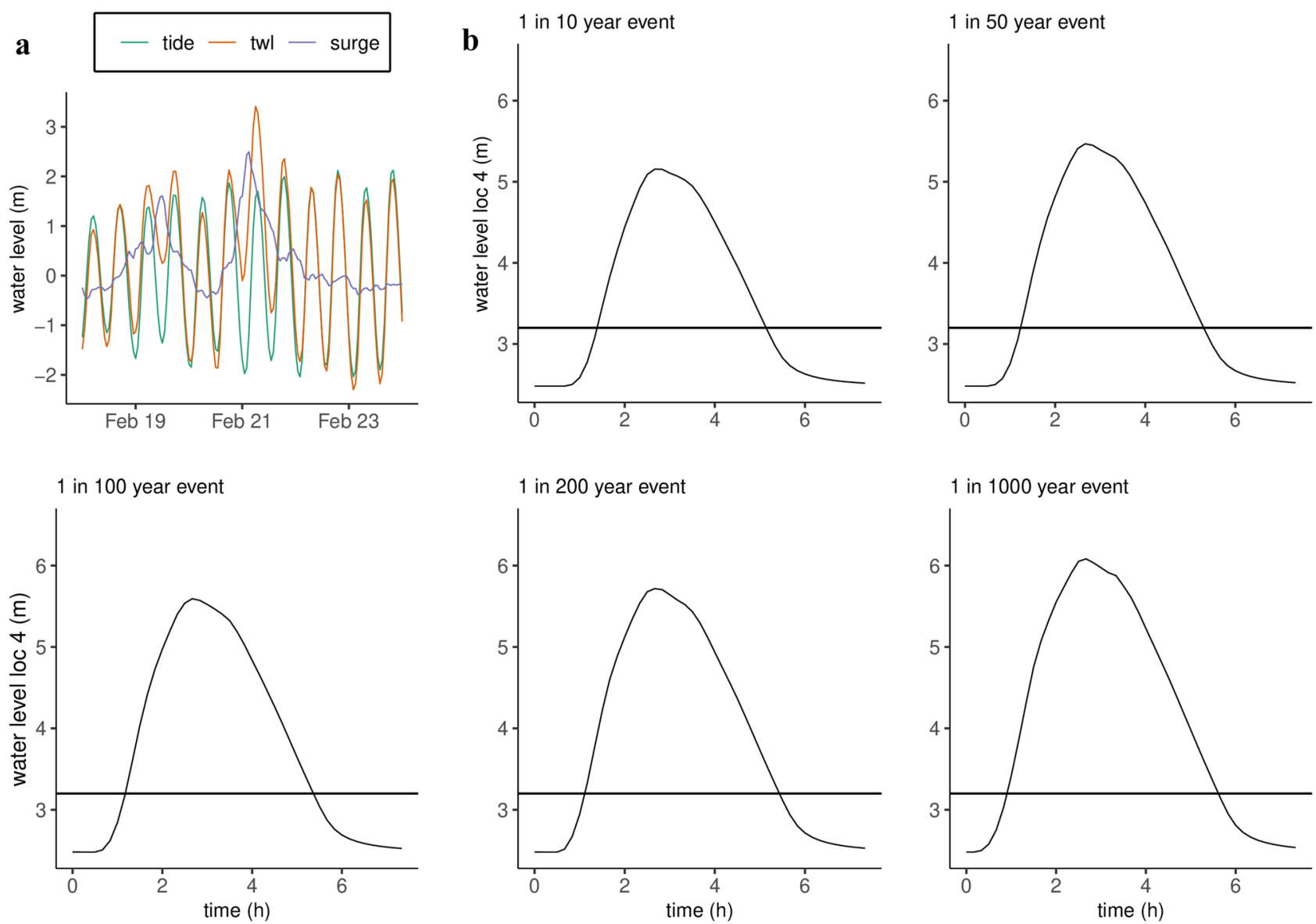

Fig. 2 a The largest storm surge on record for the tide gauge of Cromer (occurred in 1993; twl = total water level). We have stretched the 1993 event to meet the five different return water levels. b Hydrographs showing the water level curve for each extreme event at Loc

These values range in the same order of magnitude compared to findings of the monitoring report, which estimated mean total vegetation cover in 2007 to be at $89 \%$ (Brown 2008). This classification (also referred to as 'Actual veg') constitutes the baseline from which we reduced vegetation cover by $50 \%, 75 \%$ and $100 \%$, the latter representing the 'no vegetation' scenario. Consequently, differences in vegetation cover between areas within the MR are much smaller compared to differences between the vegetation scenarios. We induced a patchy vegetation cover for each scenario by applying a likelihood filter $(50 \%, 75 \%$ and $100 \%)$ to every cell classified as saltmarsh, determining whether that cell became tidal flat/mudflat or remained vegetated. The resulting land cover maps (Fig. 3) were used to derive adjusted Manning's $n$ coefficients for each changed cell.

\section{Calculation of HWL Attenuation Rates}

HWL attenuation rates $\left(\mathrm{cm} \mathrm{km}^{-1}\right)$ were calculated from the vertical difference in HWL between two observation
4 (see Fig. 1a for location). The horizontal line indicates the average elevation inside the MR site. These hydrographs were used to define boundary conditions at the eastern open boundary (Fig. 1a)

points ( $n=1$ for each observation point and return water level scenario), termed hereafter as transect, and the horizontal distance between them. All observation points are located on the marsh platform. In total, seven transects were established, where negative values refer to the amplification of HWLs and positive values indicate attenuation. Coordinates and elevations of each location are provided in Table 1. We differentiate the transects based on their location, with transects Loc 3-1, Loc 6-15 and Loc 9-14 classified as 'From Outside Breached to New Dike', while Loc 13-1, Loc 2-1, Loc 8-15 and Loc 16-14 are classified as 'Inside MR', the latter of which refers to withinwetland attenuation of HWLs. Setup of these transects was the same for Freiston Shore and all MR width variations tested.

In addition to the calculation of HWL attenuation rates at the transects, we analysed differences in absolute HWLs between locations in front of the breached, seaward dike and in front of the new, landward dike for Freiston Shore and scenario 1.4. These additional locations are abbreviated with 

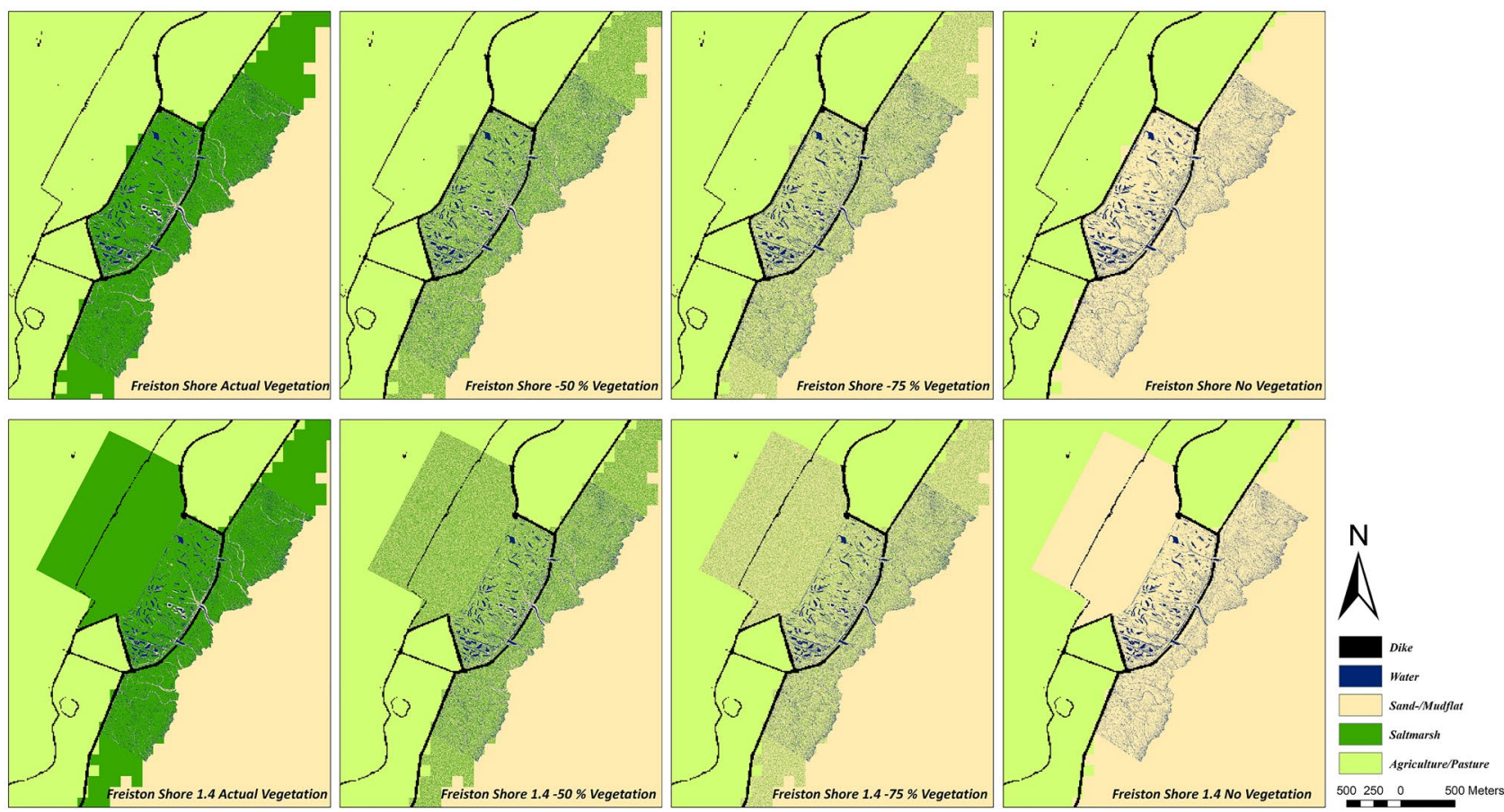

Fig. 3 Landcover maps showing the vegetation scenarios. Top row: Freiston Shore and bottom; scenario 1.4

LD (landward dike) and SD (seaward dike) and are shown in Fig. 1a, d.

Finally, we computed HWLs for locations within the three breaches, in order to compare these values with measurements from directly in front of the breached dike (Locs $3,6,9$ and SD1 and 2).

\section{Statistical Analyses}

We tested the null hypothesis that there are no significant differences in HWL attenuation rates between both the return water level and vegetation scenarios. For both variables, we tested the assumptions for conducting a two-way analysis of variance model (ANOVA). In those cases where data were neither normally distributed (as indicated by Shapiro-Wilk $p$-value $<0.05$ ) nor homoscedastic (Bartlett $p$-value $<0.05$ ), we used a Kruskal-Wallis test as non-parametric alternative. Further, we tested the null hypothesis that there was no significant difference between the two transect types, over which HWL attenuation rates were calculated ("Inside MR" and "From Outside Breached to New Dike") using the nonparametric Wilcoxon rank-sum test (assumptions for $t$-test not met). We also tested whether HWL attenuation rates for the status quo (original Freiston Shore MR site) were significantly different from 0 and whether scenarios 1.3 and 1.4 were different to the status quo, using the Wilcoxon ranksum test. Statistics and figures (despite maps) were produced with R-Studio software (R Core Team 2019).

\section{Results}

\section{Reduction of Extreme HWLs Over the Freiston Shore MR Site}

Our results show that the capacity of the Freiston Shore MR site to reduce extreme HWLs is generally low, ranging from -21 to $7 \mathrm{~cm} \mathrm{~km}^{-1}$ with an average of $-3 \mathrm{~cm} \mathrm{~km}^{-1}$ for all extreme events and vegetation scenarios (negative values represent an amplification of HWLs and positive indicate HWL attenuation). We found that HWL attenuation rates do not significantly differ between individual events and vegetation scenarios (Fig. 4; Table S1). For a comprehensive overview of HWL attenuation rates and the results of statistical tests for Freiston Shore and all MR width scenarios, we refer the reader to Table S1, provided in the online resource to this article.

The results demonstrate that water levels are generally not attenuated from the seaward, breached dike to the new, landward dike. On the contrary, HWLs are generally amplified. This trend is significantly different from zero (Wilcoxon rank-sum test $p$-value $<0.0005)$. Looking into the transects individually shows that the negative outliers in Fig. 4 in all scenarios mostly come from transect Loc $9-14$, in the south of the study site, underlining the high spatial variability of HWL attenuation (HWL attenuation rates plotted per transect are shown in Fig. S1 in the online resource to this article). The difference in HWL attenuations between the two 
Table 1 Number, coordinates and elevation of locations used to calculate HWL attenuation rates. Coordinates are given in British National Grid and elevation of measurement locations was extracted from the model topography. SD and LD refer to seaward and landward dike, respectively

\begin{tabular}{|c|c|c|c|c|c|}
\hline Area & Function & Location no & Latitude & Longitude & $\begin{array}{l}\text { Elevation } \\
(\mathrm{m} \mathrm{ODN})\end{array}$ \\
\hline \multirow[t]{18}{*}{ Status Quo } & \multirow{13}{*}{$\begin{array}{l}\text { Used to calculate HWL attenuation rates } \\
\text { for every MR width scenario }\end{array}$} & Loc 1 & 540,728 & 343,438 & 3.48 \\
\hline & & Loc 2 & 541,059 & 343,229 & 3.23 \\
\hline & & Loc 3 (SD) & 541,154 & 343,281 & 3.4 \\
\hline & & Loc 6 (SD) & 541,044 & 342,920 & 3.39 \\
\hline & & Loc 7 & 540,544 & 342,144 & 3.13 \\
\hline & & Loc 8 & 540,949 & 343,061 & 3.24 \\
\hline & & Loc 9 (SD) & 540,518 & 342,202 & 3.54 \\
\hline & & Loc 11 & 540,799 & 343,378 & 3.29 \\
\hline & & Loc 12 & 540,768 & 343,405 & 3.32 \\
\hline & & Loc 13 & 541,076 & 343,390 & 3.1 \\
\hline & & Loc 14 (LD) & 540,205 & 342,594 & 3.32 \\
\hline & & Loc 15 (LD) & 540,590 & 343,239 & 3.32 \\
\hline & & Loc 16 & 540,503 & 342,494 & 3.04 \\
\hline & \multirow{10}{*}{$\begin{array}{l}\text { Used to calculate absolute HWLs at } \\
\text { seaward and both landward dikes (SQ } \\
\text { \& 1.4) }\end{array}$} & SD1 & 540,691 & 342,361 & 3.33 \\
\hline & & $\mathrm{SD} 2$ & 540,858 & 342,590 & 3.6 \\
\hline & & LD1 & 540,734 & 343,514 & 3.42 \\
\hline & & LD2 & 540,511 & 343,090 & 3.23 \\
\hline & & LD3 & 540,385 & 342,851 & 3.3 \\
\hline \multirow[t]{8}{*}{1.4} & & LD1.4.1 & 539,438 & 343,136 & 2.48 \\
\hline & & LD1.4.2 & 539,554 & 343,358 & 3.07 \\
\hline & & LD1.4.3 & 539,699 & 343,631 & 2.97 \\
\hline & & LD1.4.4 & 539,821 & 343,861 & 2.85 \\
\hline & & LD1.4.5 & 539,964 & 344,136 & 2.55 \\
\hline & \multirow[t]{3}{*}{ Compare HWLs between SD and breaches } & Breach1 & 541,104 & 343,207 & 2.02 \\
\hline & & Breach2 & 540,933 & 342,776 & 0.12 \\
\hline & & Breach3 & 540,734 & 342,441 & 1.2 \\
\hline
\end{tabular}

transect types ("From Outside Breached to New Dike" (average $-5 \mathrm{~cm} \mathrm{~km}^{-1}$ ) and "Inside MR" (referring to withinwetland attenuation) (average $\left.-1 \mathrm{~cm} \mathrm{~km}^{-1}\right)$ ) is statistically significant (Wilcoxon rank-sum test $p$-value $<0.0005$ ).

On average, absolute HWLs at the landward dike were $2 \mathrm{~cm}$ higher compared to the breached, seaward dike. Please see the online resource for further details (Fig. S2).

\section{MR Width Thresholds Related to HWL Attenuation and Reduction of Extreme Water Levels over Each MR Width Scenario Under Full Vegetation Cover}

The modelled HWL attenuation rates of the MR width scenarios indicate that substantial areas are required to effectively reduce the highest surges at the open coast (Fig. 4). We identified surge-specific MR width thresholds for the HWL attenuation potential of Freiston Shore (Fig. 5). When full vegetation coverage is assumed, the 10-year event would require a MR width of $>1148 \mathrm{~m}$ to be attenuated, the 50-year event a width of $>1247 \mathrm{~m}$, the 100 -year event $>1277 \mathrm{~m}$ and the 200-year event requires at least $1302 \mathrm{~m}$. Since the 1000-year event was not attenuated in all scenarios, a width threshold could not be identified.

Scenarios 1.1 and 1.2 produced average HWL attenuation rates of $-4 \mathrm{~cm} \mathrm{~km}^{-1}$ and range in the same order of magnitude compared to the original Freiston Shore MR site, despite marsh widths being approximately twice the original (900 $\mathrm{m}$ and $1100 \mathrm{~m}$ in comparison to $530 \mathrm{~m}$ in the Status Quo). As for the Status Quo, no statistically significant difference in HWL attenuation rates between extreme events was identified (see online resource Table S1).

In contrast, average $\mathrm{HWL}$ attenuation rates of $2 \mathrm{~cm} \mathrm{~km}^{-1}$ were measured for scenario 1.3, comprising $1320 \mathrm{~m} \mathrm{MR}$ width and an area of 180 ha. Even though no statistically significant difference between extreme events was found (see online resource Table S1), maximum HWL attenuation rates were higher for lower surge heights. Contrary to all other scenarios tested, no amplification was observed. We note, however, that similar to scenarios 1.1 and 1.2, scenario 1.3 was only modelled with actual (full) vegetation cover. HWL attenuation rates were statistically significantly different compared to the Status Quo (Wilcoxon rank-sum test $p$-value $<0.0005)$. 
Fig. 4 HWL attenuation rates for Freiston Shore and the MR width scenarios under all extreme water level scenarios. Freiston Shore and scenario 1.4 were additionally modelled with four scenarios of reduced vegetation cover. The boxplot is defined as follows: The bottom and top ends of the box refer to the 25 th and 75 th percentile and the centreline shows the median. The whiskers are calculated as the upper and lower boundary of the box $+1.5 *$ the interquartile range. Points that did not fall within this range are plotted as outliers

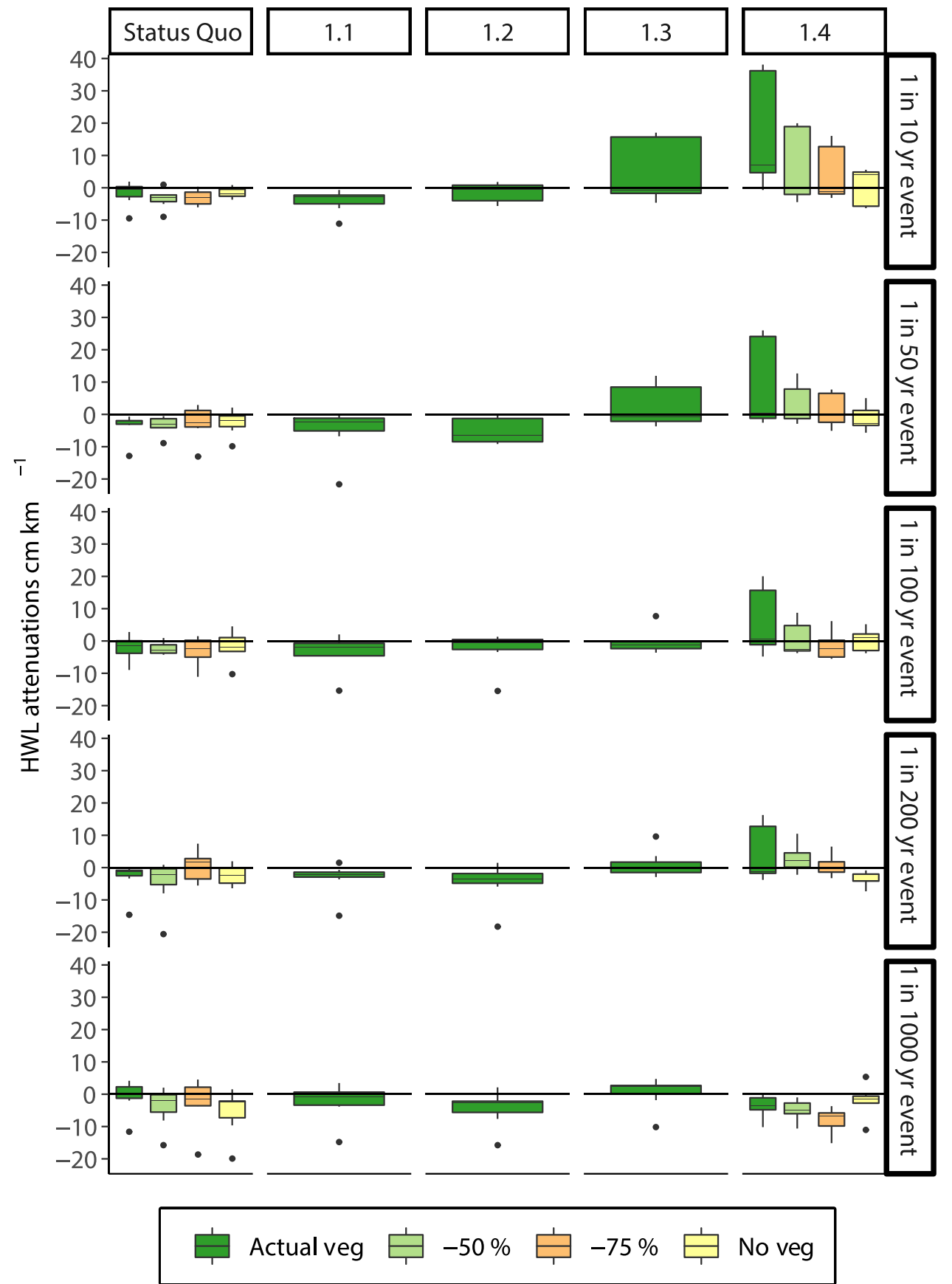

Scenario 1.4 comprises a total area of 205 ha and a $1500 \mathrm{~m}$ width, and is the only scenario which experiences substantial HWL attenuation rates. Mean HWL attenuation rate over all surges was $7 \mathrm{~cm} \mathrm{~km}^{-1}$, with decreasing values as surge heights increase (Fig. 4; online resource Table S1). The difference in HWL attenuation rates between extreme events was statistically significant (Kruskal-Wallis $p$-value $=0.02$ ), and amplification of HWLs was only observed for the 1000-year event. HWL attenuation rates were statistically significantly different to the Status Quo (Wilcoxon-rank-sum $p$-value $=0.0008$ ).
Most of the modelled attenuation in scenario 1.4 comes from transects measured from outside the breached, seaward to the landward dike, while attenuations from exclusively inside the MR are negligible (Fig. 6). The difference between both transect types was statistically significant (Wilcoxon rank-sum test $p$-value $<0.0005)$. Transects from exclusively inside the MR refer to within-wetland attenuation. Under full vegetation cover, average within-wetland attenuation of HWLs exhibits $-1 \mathrm{~cm} \mathrm{~km}^{-1}$, while transects measured from outside breached to new dike show average HWL attenuation rates of $18 \mathrm{~cm} \mathrm{~km}^{-1}$. We find that most of the attenuation 
Fig. 5 Regression between HWL attenuation rates and MR width. A second-order polynomial function was fitted through the data points, which show the average HWL attenuation rate per scenario (considering only actual (full) vegetation cover). The grey area around the regression line indicates the $95 \%$ confidence interval, and the vertical bars show the standard error of the mean

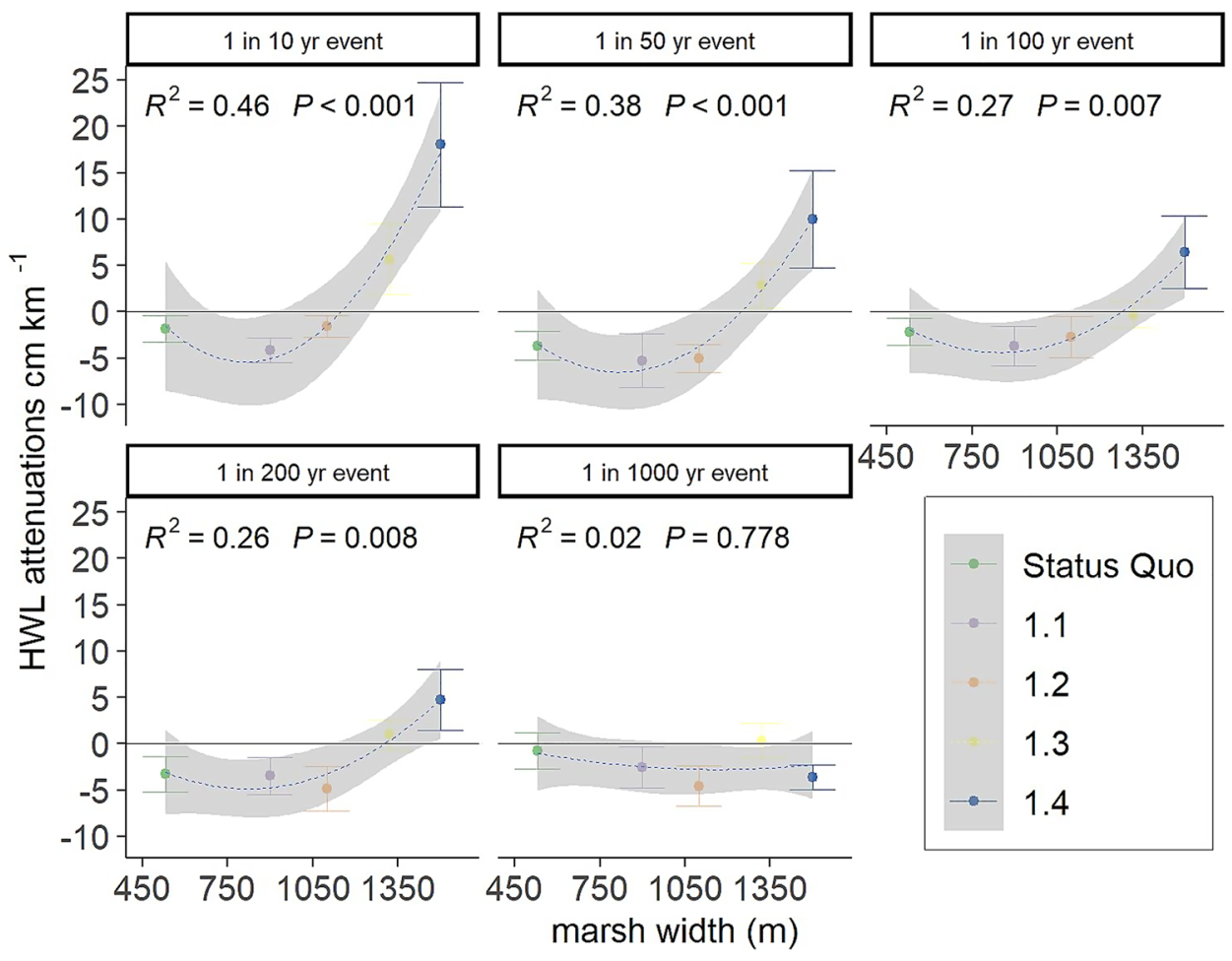

from the transects classified as from outside breached to new dike occurs within only approximately $30 \mathrm{~m}$, between locations directly in front of the breached dike and within the three breaches, or directly landward the breached dike. Over all extreme events, the average difference in absolute HWLs between the breaches and the area in front of the breached dike is $9 \mathrm{~cm}$ (Fig. 7).

Overall, HWL attenuation rates in all scenarios are characterised by high variability, expressed in standard deviations ranging from 3 to $18 \mathrm{~cm} \mathrm{~km}^{-1}$ (Table S1). Higher variabilities were observed for scenarios 1.3 and 1.4, coinciding with higher attenuation rates.

\section{Effects of Reduced Vegetation Cover on HWL Attenuation in Scenario 1.4}

Our results show that HWL attenuation rates generally decrease with decreasing vegetation cover (Fig. 4). However, statistically significant differences were only observed for the 200- and 1000-year events (Table S1). Looking at absolute differences in HWLs between locations in front of the breached, seaward and landward dikelines (green and blue points in Fig. 1d) reveals that effective reductions in HWLs are observed for all but the 1000-year event, ranging from $17 \mathrm{~cm}$ for the 10 -year event to $6 \mathrm{~cm}$ for the 200year event (Fig. 8; Table 2). However, the loss of vegetation reduces differences in HWLs between both dikelines to $1 \mathrm{~cm}$ for the 10-, 50-, and 100-year events. In addition, attenuation switches to amplification for the 200-year event when vegetation is completely lost. The 1000 -year event was amplified regardless of whether full or absent vegetation cover was modelled.

Transects classified as "Inside MR" suggest that withinwetland attenuation is low irrespective of vegetation cover. Full vegetation cover results in HWL attenuation rates of $-1 \mathrm{~cm} \mathrm{~km}^{-1}$, and absent vegetation produces rates of $-2 \mathrm{~cm} \mathrm{~km}^{-1}$.

\section{Discussion}

\section{Suitability of MR for Effective Coastal Flood Risk Reduction and Implications for Management}

The MR site of Freiston Shore is situated at the open coast of The Wash embayment. Thus, our findings are related to within-wetland attenuation of HWLs, whereas the water storage capacity (relevant for along-estuary attenuation) is negligible (Hofstede 2019; Smolders et al. 2015). Our findings suggest that at the open coast, within-wetland attenuation has to be further grouped into transects that are measured exclusively inside the MR (which essentially equates to withinwetland attenuation) and those where the first measurement point is located in front of the breached dike.

We found that the capacity of the Freiston Shore MR site to provide within-wetland attenuation is very limited. This has been shown before for the highest astronomical spring tides in both field and modelling studies (Kiesel et al. 2019, 
Fig. 6 HWL attenuation rates over scenario 1.4 depicted per transect, extreme event and vegetation scenario

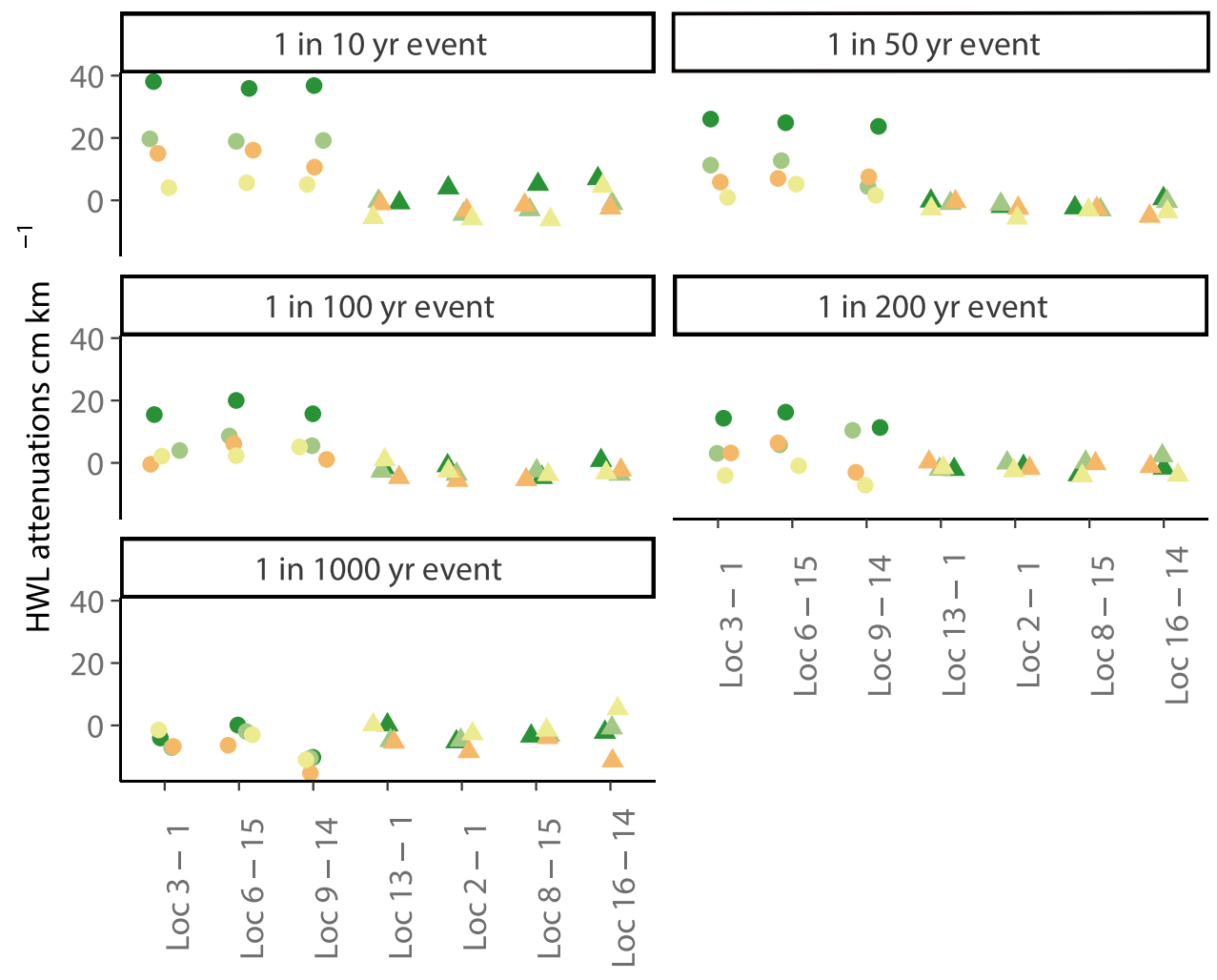

\begin{tabular}{|lll|}
\hline Actual veg & $-50 \%$ & $\bullet$ \\
$-75 \%$ & No veg & $\Delta$ Inside MR \\
\hline
\end{tabular}

2020) and, according to our results, is also valid for a range of extreme events. The comparatively weak performance of the Freiston Shore MR site is not surprising, since previous studies have shown that surge attenuation decreases if surge duration is long compared to the time it takes to fill the storage area (Resio and Westerink 2008; Loder et al. 2009). In this study, all modelled events were long and high enough to fully inundate the original MR (and all MR width scenarios). Even though our results suggest that MR at Freiston Shore has generally led to slight amplifications of HWLs, we argue that flood risks are not exacerbated under the most extreme events since amplification rates are very small, ranging between -1 and $-3 \mathrm{~cm} \mathrm{~km}^{-1}$ under actual (full) vegetation cover (Table S1).

The dominant amplification of HWLs over Freiston Shore (even if mostly small) and the gradually increasing attenuation rates for larger MR widths indicate that the capacity of MR schemes equal in size or smaller than Freiston Shore to effectively provide within-wetland attenuation may be limited, as also discussed in Hofstede (2019) and shown in Kiesel et al. (2020). This is further clarified by previously measured and modelled HWL attenuations, ranging between
$4 \mathrm{~cm} \mathrm{~km}^{-1}$ (Lovelace 1994; McGee et al. 2006; Wamsley et al. 2010) and $25 \mathrm{~cm} \mathrm{~km}^{-1}$ (McGee et al. 2006; Wamsley et al. 2010). These rates were measured over several kilometres. Consequently, the within-wetland attenuation capacity of many MR schemes in Europe today may be limited, since as of 2021, 46\% of MR schemes were smaller than 20 ha (ABPmer 2021) (compared to 66 ha in Freiston Shore). We note, however, that the capacity of smaller MR schemes to support along-estuary attenuation of HWLs may still be effective, particularly when placed further upstream in the estuary (Smolders et al. 2015; Leuven et al. 2019).

Our results show that at the open coast, only very large MR schemes can effectively contribute to coastal flood risk reduction (in terms of HWL attenuation). Site-dependent MR width thresholds for the tested extreme water level scenarios range between $1148 \mathrm{~m}$ for the 10-year event and $1302 \mathrm{~m}$ for the 200 -year event. On the other hand, the 1000year event was not attenuated in any of the MR width scenarios, suggesting that for such events, wider areas are required to achieve attenuation. The 200-year event illustrates the importance of a comprehensive vegetation cover, which can increase inundation depth thresholds until HWLs are 


\section{- 1 in 10yr event $\Delta 1$ in 50yr event - 1 in 100yr event +1 in 200yr event $\quad 1$ in 1000yr event}

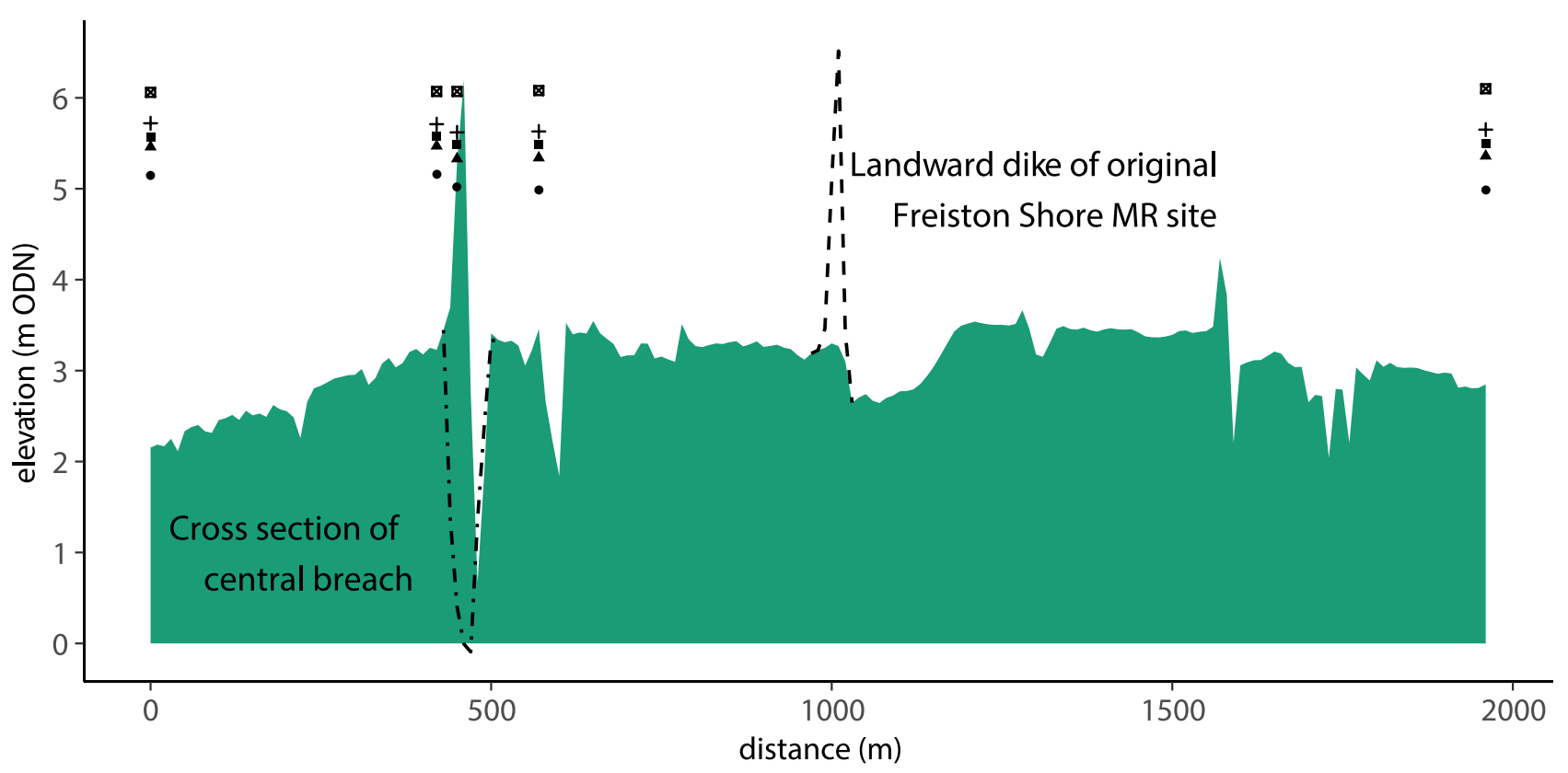

Fig. 7 Elevation profile of scenario 1.4 (green shaded area), measured from the pioneer zone of the adjacent natural saltmarsh via the central breach in landward direction to the end of the model domain. The shaped points show absolute HWLs for each extreme event for the respective location along the profile. These values were calculated as

effectively reduced (attenuation under full vegetation cover and amplification when vegetation is lost: Table 2; Fig. 8).

Under most conditions in scenario 1.4, HWLs are substantially lower at the new, landward seawall, suggesting that it can be of a lower design specification, and thus cheaper to build and maintain (Dixon et al. 1998; Pethick 2002). Indeed, most of this HWL attenuation comes from transects measured from outside the breached, seaward dike to the new, landward one, suggesting that HWLs are affected by reflection against the dike remnants (Fig. 6). Differences between absolute HWLs from locations in front of the breached dike, inside the three breaches and directly landwards support this idea (Fig. 7). Over all extreme events, the average difference in HWLs between the breaches and the area in front of the breached dike is $9 \mathrm{~cm}$, despite the locations being less than $30 \mathrm{~m}$ apart. We therefore assume that extrapolating the attenuation rates from transects classified as "From Outside Breached to New Dike" of scenario 1.4 (on average $18 \mathrm{~cm} \mathrm{~km}^{-1}$ for full vegetation cover) may lead to overestimations, as much of it comes from the effects of the breached, seaward dike.

We deduce the following management implications from the findings presented in this paper: follows (from left to right): Loc 4; average of Locs 3, 6, 9, SD1 and 2; average HWL of southern, central and northern breach; average of Locs 2, 8, 13 and 16 and; average of LD1.4.1, 1.4.2, 1.4.3, 1.4.4 and 1.4 .5

1. At the open coast, large MR schemes can effectively reduce a large range of extreme surges, but the most extreme events are not as effectively attenuated. The potential for surge attenuation scales with MR width.

2. Most of the attenuation in scenario 1.4 may come from water piled up at the remnants of the breached dike. However, lower water levels at the landward dike still mean that it can be of lower design specification compared to the breached dike and should thus be less expensive in terms of construction and maintenance costs.

3. When larger MR sites are implemented for the purpose of coastal protection, the successful re-establishment of vegetation is crucial to attenuate very high storm surge levels (in this case the 200-year event). This involves careful consideration of actual (and presumably future) inundation frequencies, fostering the establishment of diverse vegetation communities (Nottage and Robertson 2005). In addition, inundation frequency and duration are dependent on the marsh's elevation relative to tidal range, and the future resilience of established vegetation depends on sustained high sedimentation rates. Marsh elevation furthermore affects bottom friction and addi- 


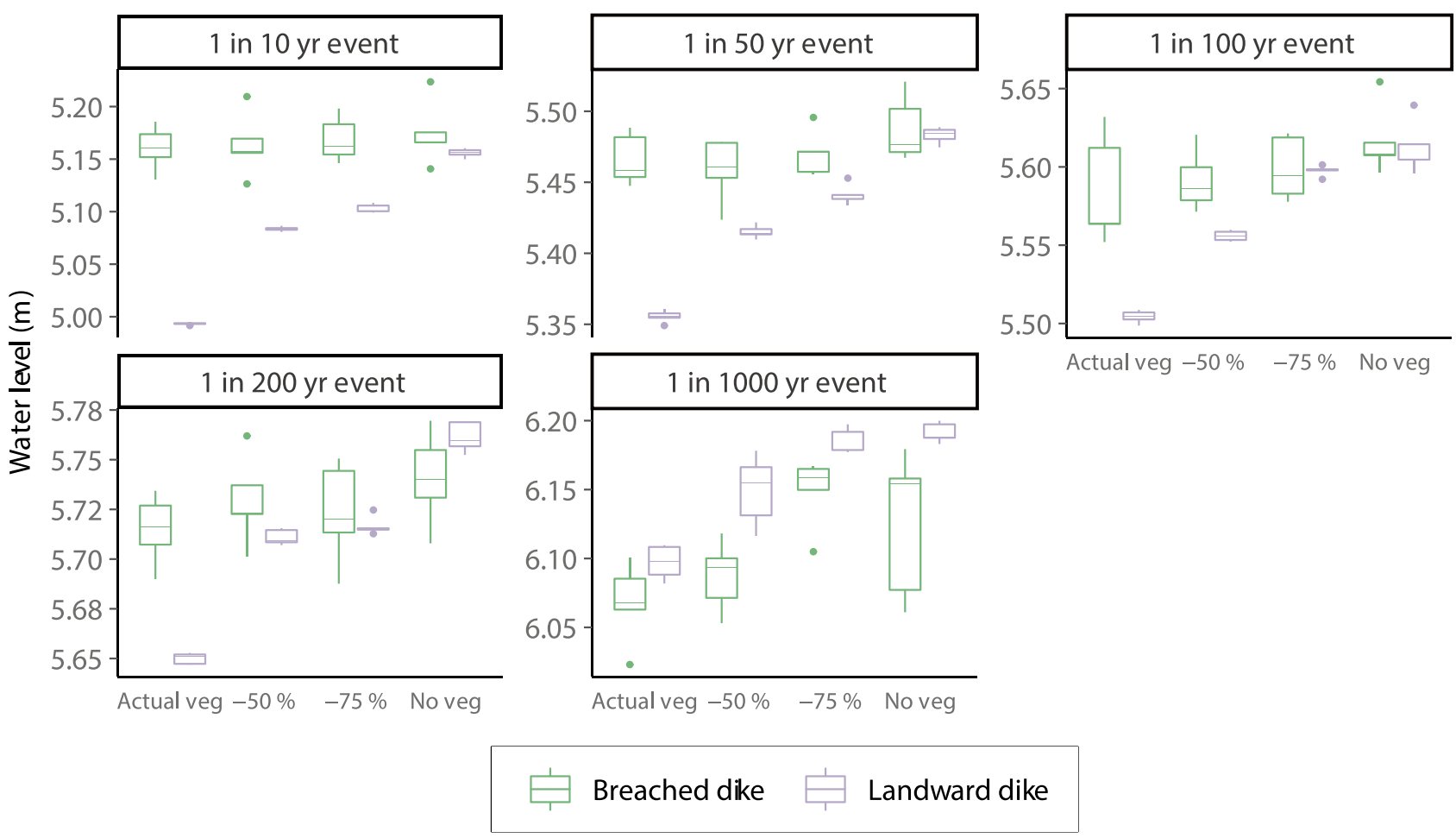

Fig. 8 Absolute HWLs (referenced to ODN) measured seaward of both the breached and hypothetical landward dike of scenario 1.4. Locations of measurements are shown in Fig. 1d and Table 1

tionally contributes to HWL attenuation (Loder et al. 2009; Wamsley et al. 2009). Sedimentation rates, site internal water depth and thus, inundation frequency and duration can be controlled by MR design (Oosterlee et al. 2020) (width of breaches in relation to site size, via RTE or by inducing synthetic tidal regimes using novel 'SmartGates' (Kiesel et al. 2020; Mulder et al. 2013; Sadat-Noori et al. 2021)).

Inundation frequency depends on the initial surface elevation of the saltmarsh to be restored, scheme design and long-term biophysical feedback mechanisms that drive site internal sediment dynamics. The first two features can be controlled by coastal planners and practitioners at the onset of MR establishment. On Wallasea island, located close to the entrance of the Thames estuary, for example, elevations were raised by $1.5 \mathrm{~m}$ prior to breaching (Cross 2017). Furthermore, the design of dike breaches can be informed by hydrodynamic modelling, and culverts and sluices enable the management of site internal inundation depths and durations. However, long-term biophysical feedback mechanisms are not yet fully understood, computationally expensive to model on a large scale and critically dependent on the development of future hydrodynamic forcing, such as sea-level rise.

Table 2 Average HWLs (referenced to ODN) measured in front of the breached and hypothetical landward dike of scenario 1.4

\begin{tabular}{|c|c|c|c|c|c|c|c|c|c|c|}
\hline & \multicolumn{2}{|l|}{ 10-year } & \multicolumn{2}{|l|}{ 50-year } & \multicolumn{2}{|l|}{ 100-year } & \multicolumn{2}{|l|}{ 200-year } & \multicolumn{2}{|l|}{ 1000-year } \\
\hline & Actual veg & No veg & Actual veg & No veg & Actual veg & No veg & Actual veg & No veg & Actual veg & No veg \\
\hline $\begin{array}{l}\text { HWL at } \\
\text { breached, } \\
\text { seaward dike } \\
\text { (m) }\end{array}$ & 5.16 & 5.17 & 5.47 & 5.49 & 5.58 & 5.62 & 5.71 & 5.74 & 6.07 & 6.13 \\
\hline $\begin{array}{l}\text { HWL at } \\
\text { hypothetical } \\
\text { landward dike } \\
\text { (m) }\end{array}$ & 4.99 & 5.16 & 5.36 & 5.48 & 5.50 & 5.61 & 5.65 & 5.76 & 6.1 & 6.19 \\
\hline Difference (m) & 0.17 & 0.01 & 0.11 & 0.01 & 0.08 & 0.01 & 0.06 & -0.02 & -0.03 & -0.06 \\
\hline
\end{tabular}




\section{Our Findings Compared to Previous Studies}

HWL attenuation rates modelled in this study within the MR site of Freiston Shore are generally lower (and, on average, negative) compared to previous assessments, which is also true for within-wetland attenuation rates in scenario 1.4. We therefore assume that the simulated extreme events may overwhelm the flow-reducing capacity of the restored saltmarsh.

A good overview of saltmarsh-related HWL attenuation rates from previous field studies is provided in Stark et al. (2015), which was later extended to some modelled results by Paquier et al. (2017). Their reviews reveal that HWL attenuation rates are generally highly variable and can range from -280 to $270 \mathrm{~cm} \mathrm{~km}^{-1}$ within a single saltmarsh (Paquier et al. 2017). However, several studies provide rates in the range of $4 \mathrm{~cm} \mathrm{~km}^{-1}$ (Lovelace 1994; McGee et al. 2006; Wamsley et al. 2010) to $25 \mathrm{~cm} \mathrm{~km}^{-1}$ (McGee et al. 2006; Wamsley et al. 2010), all of which measured over several kilometres. When shorter transects on the vegetated marsh platform were measured, values increased and reached $70 \mathrm{~cm} \mathrm{~km}^{-1}$ (Stark et al. 2015) or even $270 \mathrm{~cm} \mathrm{~km}^{-1}$ (Paquier et al. 2017). The inverse relationship between transect length and HWL attenuation has also been suggested by Kiesel et al. (2019) for the MR site of Freiston Shore. Kiesel et al. (2019) assume that short transects over saltmarsh surfaces often generate maximum (densely vegetated) or minimum friction (bare sediments) on the water column, depending on the surface cover and topography of the respective transect. This effect may be averaged over the entire marsh width, resulting in generally lower and less variable HWL attenuation rates when measured over longer distances (Kiesel et al. 2019).

\section{Model Limitations}

\section{The Missing Link—Model Validation for Extreme Events}

The model presented in this paper has been validated against field measurements of the highest spring tides of the year 2017 (Kiesel et al. 2020). These were considerably lower compared to the extreme events generated in this study. Since no measurements exist to validate the results of our model against comparative extreme water levels, we have qualitatively compared our HWL attenuation rates with results from previous assessments ("Our Findings Compared to Previous Studies"). The results are in the same order of magnitude, but without field validation data, the high storm scenarios should be viewed with caution. Since extreme surges are inherently rare events, it is not surprising that only little field data exist. However, in order to predict the effectiveness of MR schemes under relevant storm conditions, gathering data on rare events is urgently required for validating model predictions (Bouma et al. 2014). Indeed, current monitoring efforts in MR schemes devote comparatively little attention to hydrodynamic and hydrogeomorphic attributes (Spencer and Harvey 2012), calling for extended monitoring campaigns, for example using self-contained automated monitoring systems (Bouma et al. 2014).

\section{Considerations on Vegetation Scenarios and Model Assumptions}

In this study, we have addressed the impact of vegetation die-off on the HWL attenuation function of saltmarshes restored in the context of MR. Thereby, we account for existing uncertainties around the long-term ecogeomorphological evolution of MR schemes in response to sea-level rise, which may cause prolonged inundation stress and the deterioration of vegetation (Schepers et al. 2020; Kirwan et al. 2010; Mariotti 2020; Vinent et al. 2021). However, some limitations to our approach are addressed in the following.

The vegetation-induced resistance on depth-averaged flow during the very high storm tides modelled in this paper may be overestimated. We have calibrated surface roughness coefficients under a range of spring tide conditions with comparatively low inundation depths, where most of the water column is influenced by vegetation-induced resistance. Thus, the selected Manning's $n$ coefficients are representative of spring tide conditions and may be too high when applied to very high inundation depths, where most of the water column is not influenced by the presence of vegetation. However, relative differences between vegetation scenarios should not be affected by this issue.

Considering patchy vegetation die-off as a consequence of sea-level rise and ponding only constitutes one mechanism of the many faces of marsh loss (Mariotti 2020; Wasson et al. 2019). The complex interrelations and biophysical feedback mechanisms potentially leading to more or less homogeneous die-off are not considered. These include marsh edge erosion, for example due to increased wave loads as the marsh profile steepens (van de Koppel et al. 2005), or channel enlargement as a consequence of changes in tidal prism (Vandenbruwaene et al. 2015; Mariotti 2018). Differences in the die-off pattern of vegetation can affect HWL attenuation rates (Temmerman et al. 2012) and, in the long term, will affect the eco-geomorphological evolution of the site.

\section{Considerations on the Effects of Morphologic Site Evolution on HWL Attenuation Rates}

Modelled HWL reductions for Freiston Shore and scenario 1.4 are representative for the current biogeomorphic state of the MR and adjacent areas. In the following, we discuss 
likely morphologic adjustments of scenario 1.4, consequential upon the removal of Freiston Shore's landward dike and subsequent changes in the tidal prism (Friess et al. 2014; Vandenbruwaene et al. 2015; Townend et al. 2016) and anticipate potential effects on our findings.

As tidal prism and related hydrodynamics determine withinsite sedimentation (Dale et al. 2017), we expect that the morphological development of all tested scenarios would be different. For example, scenario 1.4, as modelled in this paper, does not contain any additional tidal creeks, connecting the original MR area with the new landward margin. Channel geometry, however, is a function of tidal prism (Friess et al. 2014), which would be substantially altered by increasing the size of the MR (Kiesel et al. 2020). We would therefore expect tidal creeks to develop at the landward margin of scenario 1.4 and to be morphologically altered in the area of the original scheme to accommodate for the increased tidal prism. Tidal creeks produce channelized flow, which results in lower attenuation rates compared to surfaces dominated by sheet flow (Stark et al. 2016). This is in agreement with the results of additional model runs that we conducted for scenario 1.4, where we extended the original tidal creeks of Freiston Shore to the new landward margin of the site (see online resource Fig. S3). The results indeed produced lower attenuation rates, suggesting that we might have overestimated HWL attenuation for scenario 1.4. However, attenuation rates measured with and without additional tidal creeks were not statistically significantly different (Wilcoxonrank-sum test $p$-value $=0.22$; online resource Fig. S4). On the other hand, differences in HWL attenuation rates between the Status Quo and scenario 1.4 with tidal creeks are not significantly different anymore, as indicated by the results of the Wilcoxon rank-sum test $(p=0.08)$.

There is an urgent need for further developing models of biophysical feedback mechanisms, enabling the projection of possible future morphologic developments within MR schemes. Recent advancements in this regard are presented by Gourgue et al. (2020), who developed a computationally efficient model to account for the impact of sub-grid-scale vegetation patches on the relationship between water flow and sediment dynamics. Such knowledge is crucial for the flood defence functionality of saltmarshes, as it defines long-term trends regarding elevation, vegetation type/coverage and features such as marsh cliffs and channels (Reed et al. 2018). The application of such models on large geographic scales and long temporal scales would be needed in order to evaluate not only the current, but also future coastal protection function of MR sites.

\section{Conclusions}

At the open coast, large MR schemes can provide effective coastal flood risk reduction, even under very high storm surge levels, as the example of scenario 1.4 has shown.
Freiston Shore, on the other hand, covers 66 ha and indeed constitutes one of the larger schemes in Europe as of today. It may yet be too small to effectively reduce HWLs, but flood risks are not exacerbated. Vegetation cover and MR width/ area are crucial for the coastal protection function of MR schemes, since they increase inundation depth thresholds up to which HWL attenuation is possible. The major contribution to the effective HWL attenuation in scenario 1.4 may come from reflection of HWLs against the remnants of the breached seaward dike, as shown by differences in HWLs between locations in front of the seaward dike and within the breaches. Even if this means that the contribution of within-wetland attenuation is comparatively low, the landward dike can be of lower design specification compared to the breached dike and should be cheaper regarding construction and maintenance costs.

We believe that the most concerning knowledge gap to be tackled by future research involves understanding long-term dynamics of biophysical feedback mechanisms and resulting eco- and morphodynamic adjustments. The latter challenges the effectivity of MR in future coastal protection schemes and thus constitutes an important research priority.

Supplementary Information The online version contains supplementary material available at https://doi.org/10.1007/s12237-021-00984-5 .

Acknowledgements The authors thank the UK Environment Agency for their open data policy and especially for providing coastal flood boundary conditions for a multitude of return periods, which has facilitated this study considerably. We also thank Deltares Delft Hydraulics for providing the Delft3D-Flow model. Particularly, Joshua Kiesel would like to thank Professor Tom Spencer, Professor Iris Möller and Elizabeth Christie for their support and the valuable and educational input during the past years.

Funding Open Access funding enabled and organized by Projekt DEAL.

\section{Declarations}

Conflict of Interest The authors declare no competing interests.

Open Access This article is licensed under a Creative Commons Attribution 4.0 International License, which permits use, sharing, adaptation, distribution and reproduction in any medium or format, as long as you give appropriate credit to the original author(s) and the source, provide a link to the Creative Commons licence, and indicate if changes were made. The images or other third party material in this article are included in the article's Creative Commons licence, unless indicated otherwise in a credit line to the material. If material is not included in the article's Creative Commons licence and your intended use is not permitted by statutory regulation or exceeds the permitted use, you will need to obtain permission directly from the copyright holder. To view a copy of this licence, visit http://creativecommons.org/licenses/by/4.0/.

\section{References}

ABPmer. 2021. The Online Managed Realignment Guide (OMREG). https://www.omreg.net/. Accessed 4 January 2021. 
Barbier, E.B., I.Y. Georgiou, B. Enchelmeyer, and D.J. Reed. 2013. The value of wetlands in protecting southeast Louisiana from hurricane storm surges. PLoS One 8 (3): e58715. https://doi.org/10. 1371/journal.pone.0058715

Baxter, P.J. 2005. The east coast big flood, 31 January-1 February 1953: A summary of the human disaster. Philosophical transactions. Series A, Mathematical, physical, and engineering sciences 363(1831):1293-1312. https://doi.org/10.1098/rsta.2005.1569

Bouma, T.J., J. van Belzen, T. Balke, Z. Zhu, L. Airoldi, A.J. Blight, A.J. Davies, C. Galvan, S.J. Hawkins, S.P.G. Hoggart, J.L. Lara, I.J. Losada, M. Maza, B. Ondiviela, M.W. Skov, E.M. Strain, R.C. Thompson, S. Yang, B. Zanuttigh, L. Zhang, and P.M.J. Herman. 2014. Identifying knowledge gaps hampering application of intertidal habitats in coastal protection: Opportunities \& steps to take. Coastal Engineering 87: 147-157. https://doi.org/10. 1016/j.coastaleng.2013.11.014

Brew, D., and A. Williams. 2002. Shoreline movement and shoreline management in The Wash, eastern England. Littoral Conference 2002, the Changing Coast Porto Portugal 313-320.

Broekx, S., S. Smets, I. Liekens, D. Bulckaen, and L. de Nocker. 2011. Designing a long-term flood risk management plan for the Scheldt estuary using a risk-based approach. Natural Hazards 57 (2): 245266. https://doi.org/10.1007/s11069-010-9610-x

Brooks, K.L., H.L. Mossman, J.L. Chitty, and A. Grant. 2015. Limited vegetation development on a created salt marsh associated with over-consolidated sediments and lack of topographic heterogeneity. Estuaries and Coasts 38 (1): 325-336. https://doi.org/10.1007/ s12237-014-9824-3

Brown, S. L. 2008. Wash Banks Flood Defence Scheme Freiston Environmental Monitoring 2007. R\&D Technical Report FD1911/TR. Joint Defra/EA Flood and Coastal Erosion Risk Management $R \& D$ Programme.

Brown, S. L., A. Pinder, L. Scott, J. Bass, E. Rispin, S. Brown, A. Garbutt, A. Thomson, T. Spencer, I. Möller, and S.M. Brooks. 2007. Wash banks flood defence scheme Freiston environment monitoring 2002 - 2006. FD 1911/TR. Joint DEFRA/EA Flood and Coastal Erosion Risk Management $R \& D$ Programme.

Christiansen, T., P.L. Wiberg, and T.G. Milligan. 2000. Flow and sediment transport on a tidal salt marsh surface. Estuarine, Coastal and Shelf Science 50 (3): 315-331. https://doi.org/10.1006/ecss. 2000.0548

Codiga, D. L. 2011. Unified tidal analysis and prediction using the UTide Matlab Functions. Technical Report 2011-01. Graduate School of Oceanography, University of Rhode Island. Narragansett, RI. Available online at ftp://www.po.gso.uri.edu/pub/downloads/codiga/pubs/2011Codiga-UTide-Report.pdf.

Cox, T., T. Maris, P. de Vleeschauwer, T. de Mulder, K. Soetaert, and P. Meire. 2006. Flood control areas as an opportunity to restore estuarine habitat. Ecological Engineering 28 (1): 55-63. https:// doi.org/10.1016/j.ecoleng.2006.04.001

Cross, M. 2017. Wallasea Island Wild Coast Project, UK: Circular economy in the built environment. Proceedings of the Institution of Civil Engineers - Waste and Resource Management 170 (1): 3-14. https://doi.org/10.1680/jwarm.16.00006

Dale, J., H.M. Burgess, and A.B. Cundy. 2017. Sedimentation rhythms and hydrodynamics in two engineered environments in an open coast managed realignment site. Marine Geology 383: 120-131. https://doi.org/10.1016/j.margeo.2016.12.001

Dangendorf, S., C. Hay, F.M. Calafat, M. Marcos, C.G. Piecuch, K. Berk, and J. Jensen. 2019. Persistent acceleration in global sealevel rise since the 1960s. Nature Climate Change 9 (9): 705-710. https://doi.org/10.1038/s41558-019-0531-8

Delft Hydraulics. 2003. User Manual Delft3D-FLOW. WL. Delft, The Netherlands: Delft Hydraulics.
Dixon, A.M., D. Leggett, and R.C. Weight. 1998. Habitat creation opportunities for landward coastal re-alignment: Essex case studies. Water and Environment Journal 12 (2): 107-112.

Doody, J.P. 2004. 'Coastal squeeze' - an historical perspective. Journal of Coastal Conservation 10 (1): 129. https://doi.org/10.1652/ 1400-0350(2004)010[0129:CSAHP]2.0.CO;2

Elahi, M.W.E., I. Jalón-Rojas, X.H. Wang, and E.A. Ritchie. 2020. Influence of seasonal river discharge on tidal propagation in the Ganges-Brahmaputra-Meghna Delta. Bangladesh Journal of Geophysical Research: Oceans 125 (11): 826. https://doi.org/10.1029/ 2020JC016417

Environment Agency. 2019a. Coastal flood boundary conditions for the UK: update 2018. User guide. SC060064/TR7. Bristol: Environment Agency.

Environment Agency. 2019b. Coastal flood boundary conditions for the UK: update 2018. Technical summary report. SC060064/TR6. Bristol: Environment Agency.

Environment Agency. 2019c. Vertical Aerial Photography Tiles RGBN 2016 20cm: Environment Agency copyright and/or database right 2019. All rights reserved. https://environment.data. gov.uk/DefraDataDownload/?Mode=survey

Environment Agency. 2020. LIDAR Composite DTM 2016 2m: Environment Agency copyright and/or database right 2020. All rights reserved. https://environment.data.gov.uk/DefraDataDownload/? Mode $=$ survey

Esteves, L.S. 2013. Is managed realignment a sustainable long-term coastal management approach? Journal of Coastal Research 65: 933-938. https://doi.org/10.2112/SI65-158.1

Esteves, L.S. 2014. Managed realignment: A viable long-term coastal management strategy? SpringerBriefs in environmental science. New York: Springer.

French, P.W. 2006. Managed realignment - The developing story of a comparatively new approach to soft engineering. Estuarine, Coastal and Shelf Science 67 (3): 409-423. https://doi.org/10. 1016/j.ecss.2005.11.035

Friess, D.A., T. Spencer, G.M. Smith, I. Möller, S.M. Brooks, and A.G. Thomson. 2012. Remote sensing of geomorphological and ecological change in response to saltmarsh managed realignment, The Wash, UK. International Journal of Applied Earth Observation and Geoinformation 18: 57-68. https://doi.org/10. 1016/j.jag.2012.01.016

Friess, D.A., I. Möller, T. Spencer, G.M. Smith, A.G. Thomson, and R.A. Hill. 2014. Coastal saltmarsh managed realignment drives rapid breach inlet and external creek evolution, Freiston Shore (UK). Geomorphology 208: 22-33. https://doi.org/10.1016/j. geomorph.2013.11.010

Garbutt, A., and M. Wolters. 2008. The natural regeneration of salt marsh on formerly reclaimed land. Applied Vegetation Science 11 (3): 335-344. https://doi.org/10.3170/2008-7-18451

Garzon, J., and C. Ferreira. 2016. Storm surge modeling in large estuaries: Sensitivity analyses to parameters and physical processes in the Chesapeake Bay. Journal of Marine Science and Engineering 4 (3): 45. https://doi.org/10.3390/jmse4030045

Gourgue, O., J. Belzen, C. Schwarz, T.J. Bouma, J. Koppel, and S. Temmerman. 2020. A convolution method to assess subgridscale interactions between flow and patchy vegetation in biogeomorphic models. Journal of Advances in Modeling Earth Systems. https://doi.org/10.1029/2020MS002116

Hinkel, J., D. Lincke, A.T. Vafeidis, M. Perrette, R.J. Nicholls, R.S.J. Tol, B. Marzeion, X. Fettweis, C. Ionescu, and A. Levermann. 2014. Coastal flood damage and adaptation costs under 21 st century sea-level rise. Proceedings of the National Academy of Sciences of the United States of America 111 (9): 3292-3297. https://doi.org/10.1073/pnas.1222469111 
Hofstede, J.L.A. 2019. On the feasibility of managed retreat in the Wadden Sea of Schleswig-Holstein. Journal of Coastal Conservation 23 (6): 1069-1079. https://doi.org/10.1007/s11852-019-00714-x

Hossain, A.K.M.A., Y. Jia, and X. Chao. 2009. Estimation of Manning's roughness coefficient distribution for hydrodynamic model using remotely sensed land cover features. In 2009 17th International Conference on Geoinformatics, 1-4. 2009 17th International Conference on Geoinformatics, Fairfax, VA. 12/08/2009 14/08/2009: IEEE. https://doi.org/10.1109/GEOINFORMATICS. 2009.5293484

Ke, X., G. Evans, and M.B. Collins. 1996. Hydrodynamics and sediment dynamics of The Wash embayment, eastern England. Sedimentology 43: 157-174.

Kiesel, J., M. Schuerch, I. Möller, T. Spencer, and A. Vafeidis. 2019. Attenuation of high water levels over restored saltmarshes can be limited: Insights from Freiston Shore, Lincolnshire, UK. Ecological Engineering 136: 89-100. https://doi.org/10.1016/j.ecoleng. 2019.06.009

Kiesel, J., M. Schuerch, E.K. Christie, I. Möller, T. Spencer, and A.T. Vafeidis. 2020. Effective design of managed realignment schemes can reduce coastal flood risks. Estuarine, Coastal and Shelf Science 242: 106844. https://doi.org/10.1016/j.ecss.2020.106844

Kirezci, E., I.R. Young, R. Ranasinghe, S. Muis, R.J. Nicholls, D. Lincke, and J. Hinkel. 2020. Projections of global-scale extreme sea levels and resulting episodic coastal flooding over the $21 \mathrm{st}$ Century. Scientific Reports 10 (1): 11629. https://doi.org/10.1038/ s41598-020-67736-6

Kirwan, M.L., G.R. Guntenspergen, A. D’Alpaos, J.T. Morris, S.M. Mudd, and S. Temmerman. 2010. Limits on the adaptability of coastal marshes to rising sea level. Geophysical Research Letters 37 (23). https://doi.org/10.1029/2010GL045489

Lawrence, D.S.L., J.R.L. Allen, and G.M. Havelock. 2004. Salt marsh morphodynamics: An investigation of tidal flows and marsh channel equilibrium. Journal of Coastal Research 20 (1): 301-316.

Lawrence, P.J., G.R. Smith, M.J.P. Sullivan, and H.L. Mossman. 2018. Restored saltmarshes lack the topographic diversity found in natural habitat. Ecological Engineering 115: 58-66. https://doi.org/10. 1016/j.ecoleng.2018.02.007

Leonard, L.A., and A.L. Croft. 2006. The effect of standing biomass on flow velocity and turbulence in Spartina alterniflora canopies. Estuarine, Coastal and Shelf Science 69 (3-4): 325-336. https:// doi.org/10.1016/j.ecss.2006.05.004

Lesser, G.R., J.A. Roelvink, J.A.T.M. van Kester, and G.S. Stelling. 2004. Development and validation of a three-dimensional morphological model. Coastal Engineering 51 (8-9): 883-915. https://doi.org/10.1016/j.coastaleng.2004.07.014

Leuven, J.R.F.W., H.J. Pierik, M. van der Vegt, T.J. Bouma, and M.G. Kleinhans. 2019. Sea-level-rise-induced threats depend on the size of tide-influenced estuaries worldwide. Nature Climate Change 9 (12): 986-992. https://doi.org/10.1038/s41558-019-0608-4

Liu, H., K. Zhang, Y. Li, and L. Xie. 2013. Numerical study of the sensitivity of mangroves in reducing storm surge and flooding to hurricane characteristics in southern Florida. Continental Shelf Research 64: 51-65. https://doi.org/10.1016/j.csr.2013.05.015

Loder, N.M., J.L. Irish, M.A. Cialone, and T.V. Wamsley. 2009. Sensitivity of hurricane surge to morphological parameters of coastal wetlands. Estuarine, Coastal and Shelf Science 84 (4): 625-636. https://doi.org/10.1016/j.ecss.2009.07.036

Lovelace, J.K. 1994. Storm-tide elevations produced by Hurricane Andrew along the Louisiana coast, August 25-27, 1992. Open-File Report: US Geological Survey. https://doi.org/10.3133/ofr94371

Marani, M., A. D’Alpaos, S. Lanzoni, L. Carniello, and A. Rinaldo. 2007. Biologically-controlled multiple equilibria of tidal landforms and the fate of the Venice lagoon. Geophysical Research Letters 34 (11): 77. https://doi.org/10.1029/2007GL030178
Mariotti, G. 2018. Marsh channel morphological response to sea level rise and sediment supply. Estuarine, Coastal and Shelf Science 209 (1225): 89-101. https://doi.org/10.1016/j.ecss.2018.05.016

Mariotti, G. 2020. Beyond marsh drowning: The many faces of marsh loss (and gain). Advances in Water Resources 144: 103710. https://doi.org/10.1016/j.advwatres.2020.103710

Mazik, K., W. Musk, O. Dawes, K. Solyanko, S. Brown, L. Mander, and M. Elliott. 2010. Managed realignment as compensation for the loss of intertidal mudflat: A short term solution to a long term problem? Estuarine, Coastal and Shelf Science 90 (1): 11-20. https://doi.org/10.1016/j.ecss.2010.07.009

McGee, Benton D., Burl B. Goree, Roland W. Tollett, Brenda K. Woodward, and Wade H. Kress. 2006. Hurricane Rita surge data, southwestern Louisiana and southeastern Texas, September to November 2005. Data Series: US Geological Survey. https://doi. org/10.3133/ds220

Möller, I., and T. Spencer. 2002. Wave dissipation over macro-tidal saltmarshes: Effects of marsh edge typology and vegetation change. Journal of Coastal Research (SI36): 506-521.

Möller, I., M. Kudella, F. Rupprecht, T. Spencer, M. Paul, B.K. van Wesenbeeck, G. Wolters, K. Jensen, T.J. Bouma, M. MirandaLange, and S. Schimmels. 2014. Wave attenuation over coastal salt marshes under storm surge conditions. Nature Geoscience 7 (10): 727-731. https://doi.org/10.1038/ngeo2251

Montgomery, J., K. Bryan, E. Horstman, and J. Mullarney. 2018. Attenuation of tides and surges by mangroves: Contrasting case studies from New Zealand. Water 10 (9): 1119. https://doi.org/ $10.3390 / \mathrm{w} 10091119$

Mossman, H.L., A.J. Davy, A. Grant, and C. Elphick. 2012. Does managed coastal realignment create saltmarshes with 'equivalent biological characteristics' to natural reference sites? Journal of Applied Ecology 49 (6): 1446-1456. https://doi.org/10.1111/j. 1365-2664.2012.02198.x

Mulder, T. de, J. Vercruysse, K. Verelst, P. Peeters, T. Maris, and P. Meire. 2013. Inlet sluices for flood control areas with controlled reduced tide in the Scheldt estuary: An overview. In Proceedings of the International Workshop on Hydraulic Design of Low-Head Structures: Aachen, Germany, February 20-22, 2013, ed. Daniel B. Bung, 43-53. Karlsruhe, Germany: BAW.

Narayan, S., M.W. Beck, B.G. Reguero, I.J. Losada, B. van Wesenbeeck, N. Pontee, J.N. Sanchirico, J.C. Ingram, G.-M. Lange, and K.A. Burks-Copes. 2016. The effectiveness, costs and coastal protection benefits of natural and nature-based defences. PLOS ONE 11 (5): e0154735. https://doi.org/10.1371/journal.pone.0154735

Nerem, R.S., B.D. Beckley, J.T. Fasullo, B.D. Hamlington, D. Masters, and G.T. Mitchum. 2018. Climate-change-driven accelerated sealevel rise detected in the altimeter era. Proceedings of the National Academy of Sciences of the United States of America 115 (9): 2022-2025. https://doi.org/10.1073/pnas.1717312115

Nottage, A., and P. Robertson. 2005. The saltmarsh creation handbook. A project manager's guide to the creation of saltmarsh and intertidal mudflat. Sandy: Royal Society for the Protection of Birds.

Oosterlee, L., T.J.S. Cox, S. Temmerman, and P. Meire. 2020. Effects of tidal re-introduction design on sedimentation rates in previously embanked tidal marshes. Estuarine, Coastal and Shelf Science 244: 106428. https://doi.org/10.1016/j.ecss.2019.106428

Paquier, A.-E., J. Haddad, S. Lawler, and C.M. Ferreira. 2017. Quantification of the attenuation of storm surge components by a coastal wetland of the US mid Atlantic. Estuaries and Coasts 40 (4): 930-946. https://doi.org/10.1007/s12237-016-0190-1

Pethick, J. 2002. Estuarine and tidal wetland restoration in the United Kingdom: Policy versus practice. Restoration Ecology 10 (3): 431-437.

R Core Team. 2019. R: A language and environment for statistical computing. Vienna, Austria: R Foundation for Statistical Computing. 
Reed, D., B. van Wesenbeeck, P.M.J. Herman, and E. Meselhe. 2018. Tidal flat-wetland systems as flood defenses: Understanding biogeomorphic controls. Estuarine, Coastal and Shelf Science 213: 269-282. https:// doi.org/10.1016/j.ecss.2018.08.017

Reguero, B.G., M.W. Beck, D.N. Bresch, J. Calil, and I. Meliane. 2018. Comparing the cost effectiveness of nature-based and coastal adaptation: A case study from the Gulf Coast of the United States. PLOS ONE 13 (4): e0192132. https://doi.org/10.1371/journal. pone. 0192132

Resio, D.T., and J.J. Westerink. 2008. Modeling the physics of storm surges. Physics Today 61 (9): 33-38. https://doi.org/10.1063/1. 2982120

Rupprecht, F., I. Möller, M. Paul, M. Kudella, T. Spencer, B.K. van Wesenbeeck, G. Wolters, K. Jensen, T.J. Bouma, M. MirandaLange, and S. Schimmels. 2017. Vegetation-wave interactions in salt marshes under storm surge conditions. Ecological Engineering 100: 301-315. https://doi.org/10.1016/j.ecoleng.2016.12.030

Sadat-Noori, M., C. Rankin, D. Rayner, V. Heimhuber, T. Gaston, C. Drummond, A. Chalmers, D. Khojasteh, and W. Glamore. 2021. Coastal wetlands can be saved from sea level rise by recreating past tidal regimes. Scientific Reports 11 (1): 1196. https://doi.org/ 10.1038/s41598-021-80977-3

Schepers, L., P. Brennand, M.L. Kirwan, G.R. Guntenspergen, and S. Temmerman. 2020. Coastal marsh degradation into ponds induces irreversible elevation loss relative to sea level in a microtidal system. Geophysical Research Letters 47 (18): 1021. https://doi.org/ 10.1029/2020GL089121

Schuerch, M., T. Spencer, S. Temmerman, M.L. Kirwan, C. Wolff, D. Lincke, C.J. McOwen, M.D. Pickering, R. Reef, A.T. Vafeidis, J. Hinkel, R.J. Nicholls, and S. Brown. 2018. Future response of global coastal wetlands to sea-level rise. Nature 561 (7722): 231-234. https://doi.org/10.1038/s41586-018-0476-5

Sheng, Y.P., A. Lapetina, and G. Ma. 2012. The reduction of storm surge by vegetation canopies: Three-dimensional simulations. Geophysical Research Letters 39 (20). https://doi.org/10.1029/ 2012GL053577

Smolders, S., Y. Plancke, S. Ides, P. Meire, and S. Temmerman. 2015. Role of intertidal wetlands for tidal and storm tide attenuation along a confined estuary: A model study. Natural Hazards and Earth System Sciences 15 (7): 1659-1675. https://doi.org/10.5194/ nhess-15-1659-2015

Spencer, T., D.A. Friess, I. Möller, S.L. Brown, R.A. Garbutt, and J.R. French. 2012. Surface elevation change in natural and re-created intertidal habitats, eastern England, UK, with particular reference to Freiston Shore. Wetlands Ecology and Management 20 (1): 9-33. https://doi.org/10.1007/s11273-011-9238-y

Spencer, T., S.M. Brooks, B.R. Evans, J.A. Tempest, and I. Möller. 2015. Southern North Sea storm surge event of 5 December 2013: Water levels, waves and coastal impacts. Earth-Science Reviews 146: 120-145. https://doi.org/10.1016/j.earscirev.2015.04.002

Spencer, T., M. Schuerch, R.J. Nicholls, J. Hinkel, D. Lincke, A.T. Vafeidis, R. Reef, L. McFadden, and S. Brown. 2016. Global coastal wetland change under sea-level rise and related stresses: The DIVA Wetland Change Model. Global and Planetary Change 139 (3): 15-30. https://doi.org/10.1016/j.gloplacha.2015.12.018

Spencer, K.L., and G.L. Harvey. 2012. Understanding system disturbance and ecosystem services in restored saltmarshes: Integrating physical and biogeochemical processes. Estuarine, Coastal and Shelf Science 106: 23-32. https://doi.org/10.1016/j.ecss.2012.04. 020
Stark, J., T. van Oyen, P. Meire, and S. Temmerman. 2015. Observations of tidal and storm surge attenuation in a large tidal marsh. Limnology and Oceanography 60 (4): 1371-1381. https://doi.org/ 10.1002/lno.10104

Stark, J., Y. Plancke, S. Ides, P. Meire, and S. Temmerman. 2016. Coastal flood protection by a combined nature-based and engineering approach: Modelling the effects of marsh geometry and surrounding dikes. Estuarine, Coastal and Shelf Science 175: 34-45. https://doi.org/10.1016/j.ecss.2016.03.027

Temmerman, S., M.B. de Vries, and T.J. Bouma. 2012. Coastal marsh die-off and reduced attenuation of coastal floods: A model analysis. Global and Planetary Change 92-93: 267-274. https://doi. org/10.1016/j.gloplacha.2012.06.001

Temmerman, S., P. Meire, T.J. Bouma, P.M.J. Herman, T. Ysebaert, and H.J. de Vriend. 2013. Ecosystem-based coastal defence in the face of global change. Nature 504 (7478): 79-83. https://doi.org/ 10.1038/nature12859

Townend, I., Z.B. Wang, M. Stive, and Z. Zhou. 2016. Development and extension of an aggregated scale model: Part 1 - Background to ASMITA. China Ocean Engineering 30 (4): 483-504. https:// doi.org/10.1007/s13344-016-0030-x

Turner, R.K., D. Burgess, D. Hadley, E. Coombes, and N. Jackson. 2007. A cost-benefit appraisal of coastal managed realignment policy. Global Environmental Change 17 (3-4): 397-407. https://doi.org/10.1016/j.gloenvcha.2007.05.006

van de Koppel, J., D. van der Wal, J.P. Bakker, and P.M.J. Herman. 2005. Self-organization and vegetation collapse in salt marsh ecosystems. The American naturalist 165 (1). https://doi.org/ $10.1086 / 426602$

Vandenbruwaene, W., C. Schwarz, T.J. Bouma, P. Meire, and S. Temmerman. 2015. Landscape-scale flow patterns over a vegetated tidal marsh and an unvegetated tidal flat: Implications for the landform properties of the intertidal floodplain. Geomorphology 231: 40-52. https://doi.org/10.1016/j.geomorph.2014.11.020

Vinent, O.D., E.R. Herbert, D.J. Coleman, J.D. Himmelstein, and M.L. Kirwan. 2021. Onset of runaway fragmentation of salt marshes. One Earth 4 (4): 506-516. https://doi.org/10.1016/j.oneear.2021. 02.013 .

Wadey, M.P., I.D. Haigh, R.J. Nicholls, J.M. Brown, K. Horsburgh, B. Carroll, S.L. Gallop, T. Mason, and E. Bradshaw. 2015. A comparison of the 31 January-1 February 1953 and 5-6 December 2013 coastal flood events around the UK. Frontiers in Marine Science 2: 793. https://doi.org/10.3389/fmars.2015.00084

Wamsley, T.V., M.A. Cialone, J.M. Smith, B.A. Ebersole, and A.S. Grzegorzewski. 2009. Influence of landscape restoration and degradation on storm surge and waves in southern Louisiana. Natural Hazards 51 (1): 207-224. https://doi.org/10.1007/ s11069-009-9378-z

Wamsley, T.V., M.A. Cialone, J.M. Smith, J.H. Atkinson, and J.D. Rosati. 2010. The potential of wetlands in reducing storm surge. Ocean Engineering 37 (1): 59-68. https://doi.org/10.1016/j. oceaneng.2009.07.018

Wasson, K., N.K. Ganju, Z. Defne, C. Endris, T. Elsey-Quirk, K.M. Thorne, C.M. Freeman, G. Guntenspergen, D.J. Nowacki, and K.B. Raposa. 2019. Understanding tidal marsh trajectories: Evaluation of multiple indicators of marsh persistence. Environmental Research Letters 14 (12): 124073. https://doi.org/10.1088/17489326/ab5a94 